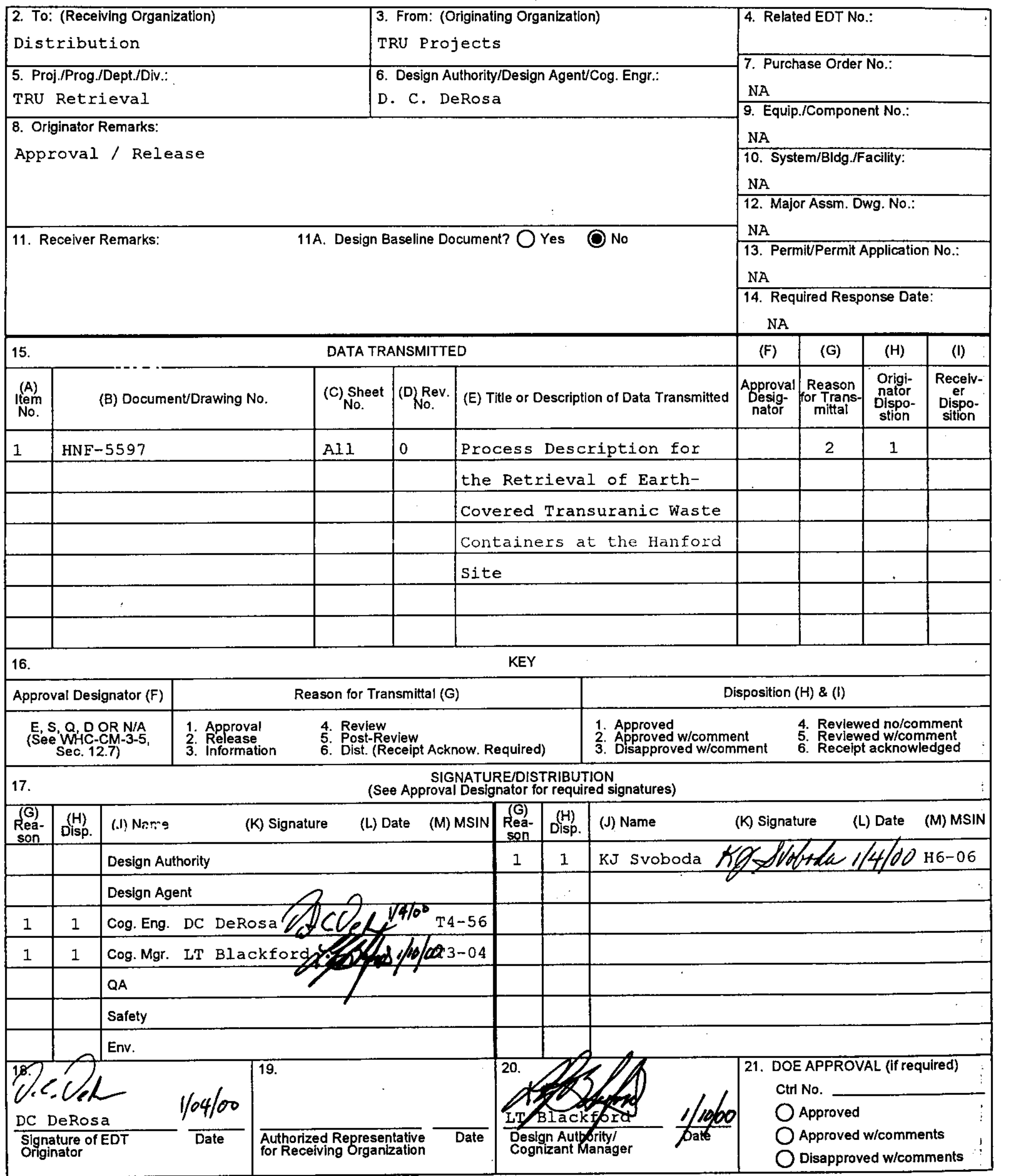




\title{
Process Description for the Retrieval of Earth-Covered Transuranic Waste Containers at the Hanford Site
}

\author{
D. R. DeRosa \\ Fluor Hanford, Inc. \\ Richland, WA 99352 \\ U.S. Department of Energy Contract DE-AC06-96RL13200
}

\author{
EDT/ECN: 619478 \\ UC: 2000 \\ Org Code: 3 T000 \\ B\&R Code: EW02J1260 \\ Charge Code: $101689 /$ AJ60/ Hmwm 0011 \\ Total Pages: 90
}

Key Words:

transuranic waste, retrieval process, drum retrieval, solid Waste Burial

Grounds, Low Level Burial Grounds, Phase I TRU Retrieval Project, W-113

Abstract:

This document describes process and operational options for retrieval of the contact-handled suspect transuranic waste drums currently stored below grade in earth-covered trenches at the Hanford site. Retrieval processes and options discussed include excavation, container retrieval, venting, non-destructive assay, criticality avoidance, incidental waste handling, site preparation, equipment, and shipping.

TRADEMARK DISCLAIMER. Reference herein to any specific commercial product, process, or service by trade name, trademark, manufacturer, or otherwise, does not necessarily constitute or Imply its endorsement, recommendatlon, or favoring by the United States Government or any agency thereof or Its contractors or subcontractors.

Printed in the United States of America. To obtain copies of this document, contact: Document Control Services, P.O. Box 950, Mallatop H6-08, Richland WA 99352, Phone (509) 372-2420; Fax (509) 376-4989.

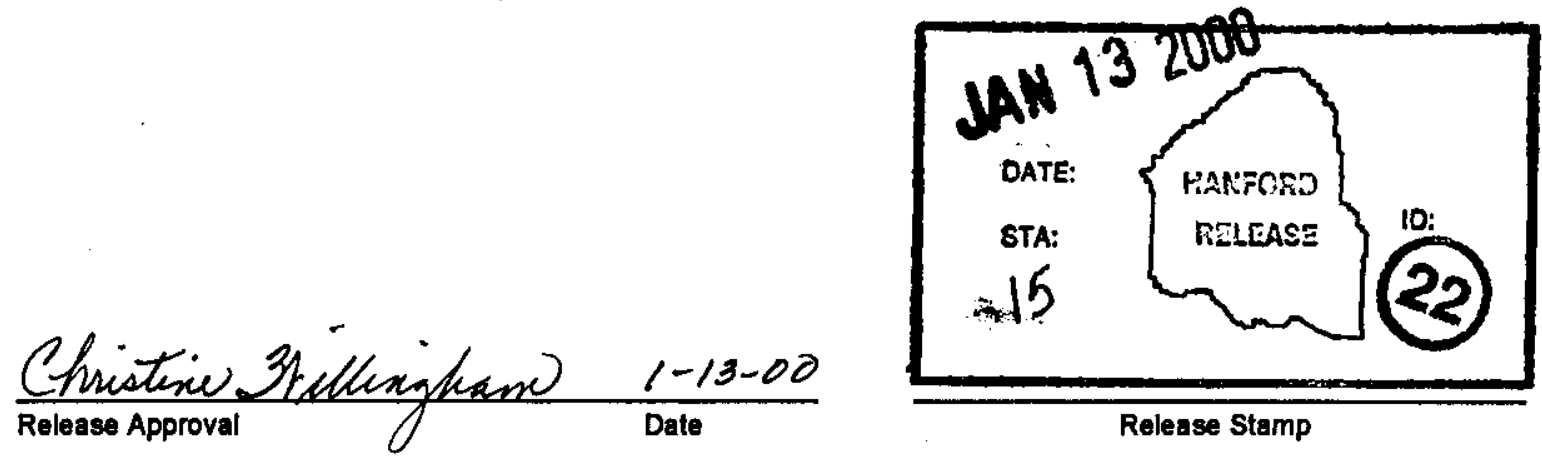

\section{Approved For Public Release}




\section{Process Description for the Retrieval of Earth-Covered Transuranic Waste Containers at the Hanford Site}

Prepared for the U.S. Department of Energy

Assistant Secretary for Environmental Management

Project Hanford Management Contractor for the

U.S. Department of Energy under Contract DE-AC06-96RL13200

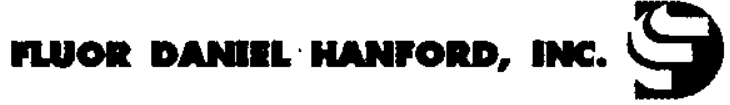

P.O. Box 1000

Richland, Washington 


\section{Process Description for the Retrieval of Earth-Covered Transuranic Waste Containers at the Hanford Site}

D. C. DeRosa

Fluor Daniel Hanford

J. W. Biglin

J. A. Demiter

COGEMA Engineering Corp.

S. L. Lindberg

J. A. Pottmeyer

Los Alamos Technical Associates

Date Published

January 2000

Prepared for the U.S. Department of Energy

Assistant Secretary for Environmental Management

rwon dakusl kawronb, inc.

P.0. Box 1000

Richland, Washington 


\title{
LEGAL DISCLAIMER
}

\begin{abstract}
This report was prepared as an account of work sponsored by an agency of the United States Government. Neither the United States Government nor any agency thereol, nor any of their employees, nor any of their contractors, subcontractors or their employees, makes any warranty, express or implied, or assumes any legal liability or responsibility for the accuracy, completeness, or any third party's use or the results of such use of any information, apparatus, product, or process disclosed, or represents that its use would not infringe privately owned rights. Reference herein to any specific commercial product, process, or service by trade name, trademark, manufacturer, or otherwise, does not necessarily constitute or imply its endorsement, recommendation, or favoring by the United States Government or any agency thereof or its contractors or subcontractors. The views and opinions of authors expressed herein do not necessarily state or reflect those of the United States Government or any agency thereof.
\end{abstract}

This report has been reproduced from the best available copy. 


\section{EXECUTIVE SUMMARY}

The Hanford Site is one of ten U. S. Department of Energy (DOE) sites that generate and/or store transuranic (TRU) wastes generated by national defense programs. In 1970, the U. S. Atomic Energy Commission (AEC) defined TRU waste as a separate waste category and declared that it must be stored in a form that is retrievable as contaminationfree packages designed to last 20 years, pending decisions on permanent disposal (AEC, 1970). Since 1970 , approximately 37,400 suspect-TRU and mixed-TRU (TRUM) waste containers have been placed in retrievable storage at the Hanford Site.

When the TRU retrievable storage began in 1970, the TRU waste definition was any "waste with known or detectable contamination of transuranium radionuclides" (AEC 1970). In 1973, the limit for TRU was specified as $10 \mathrm{nCi} / \mathrm{g}$ of waste, and, in 1982, the limit was revised upward to $100 \mathrm{nCi} / \mathrm{g}$. Because of the changes in the definition of TRU waste as well as the methods by which waste was determined to be TRU, some fraction of the waste initially disposed of as TRU is considered to be LLW under current definitions.

The majority of Contact-Handled $(\mathrm{CH})$ TRU waste drums at Hanford (approximately 26,200 ) are stacked vertically on asphalt pads in earth-covered trenches in the Solid Waste Burial Grounds (SWBG). These drums will be retrieved, visually checked for structural integrity, and, if necessary, placed in an overpack container. If the records indicate that the TRU content of the container is less than 1 gram, the container will be non-destructively assayed to determine if the waste is TRU or Low Level Waste (LLW).

The LLW containers will remain disposed of in the SWBG, and the TRU waste drums will be transported from the burial ground to a Treatment, Storage or Disposal (TSD) facility where they will be staged prior to being accepted into Hanford's Waste Isolation Pilot Plant (WIPP) Certification Program. Certified TRU waste containers will be sent to WIPP for final disposal. A small percentage of TRU drums are expected to require special handling or processing that would preclude their retrieval from the SWBG during the Phase I Retrieval Project. These drums as well as TRU waste containers other than drums will remain in the SWBG pending disposition at a later date.

This document presents a process description for the retrieval of earth-covered, CH-TRU waste drums located in the SWBG. This description provides the basis for the design of the retrieval process that will be used to meet the M-91-07 milestones for Phase I TRU retrieval and to provide data for Phase II TRU retrieval. This process description was developed after reviewing the current SWBG Interim Safety Basis and previous TRU retrieval projects and their associated activities. These retrieval projects included the Hanford Pilot TRU Drum Retrieval Project, the Savannah River Site (SRS) TRU Retrieval Project, and the Los Alamos National Laboratory (LANL) TRU Retrieval Project (also known as the Transuranic Waste Inspection/Storage Project [TWISP]). This review enabled lessons learned and process optimization efforts from prior TRU retrieval efforts to be incorporated into the retrieval process presented in this document. 
The overall retrieval strategy addresses:

- Pre-Start Activities

- Excavation Activities

- Inspection and Retrieval Activities

- Non-Destructive Assay
- Disposition of Drums for Storage or Disposal

- Drum Venting (as required)

- Documentation Requirements

- Special Handling Issues.

This document provides a description of each activity and associated sub-activities for the retrieval of earth-covered TRU containers. Following each description, a summary of similar activities for the related projects (SWBG, Hanford Pilot Retrieval, LANL TWISP, and SRS) is provided, as applicable. 


\section{TABLE OF CONTENTS}

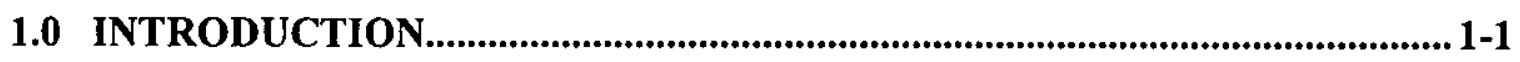

1.1. PURPOSE

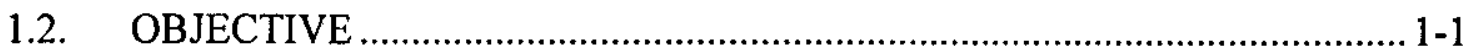

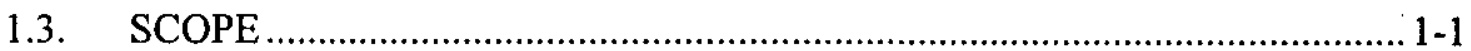

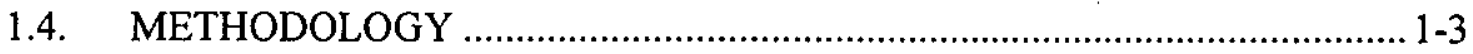

1.5. UNCERTAINTIES AND ASSUMPTIONS ............................................ 1-3

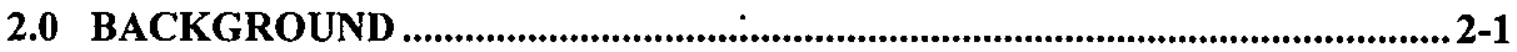

2.1. TRU RETRIEVABLE STORAGE IN SWBG TRENCHES ….....................2-1

2.2. TRU WASTE RETRIEVAL PLANS AT HANFORD …............................. 2-5

2.3. PREVIOUS TRU RETRIEVAL EXPERIENCE ....................................... 2-6

2.4. SWBG SAFETY AUTHORIZATION BASIS ............................................. 2-9

3.0 PROCESS OVERVIEW ....................................................................................... 3-1

3.1. STRATEGY AND APPROACH....................................................................

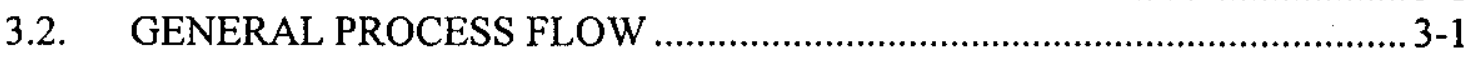

4.0 PRE-START ACTIVITIES ........................................................................ 4-1

4.1. RETRIEVAL OF HISTORICAL RECORDS ......................................... 4-1

4.2. SITE SET-UP AND PREPARATION ............................................. 4-3

4.3. SET-UP AND INSPECTION OF NDA EQUIPMENT …......................... 4-5

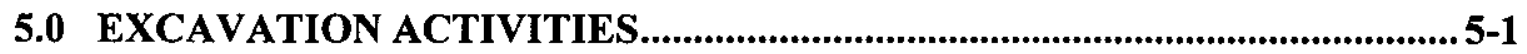

5.1. UNCOVERING OF DRUMS ...................................................................

5.2. MONITORING AND INSPECTION DURING EXCAVATION

5.3. HANDLING AND STORAGE OF CONTAMINATED SOILS ...................5-5

5.4. PLACEMENT AND HANDLING OF SPOIL PILES .................................... 5-6

5.5. REMOVAL AND DISPOSITION OF TARP AND PLYWOOD

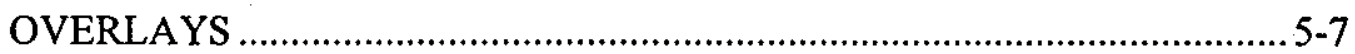

6.0 INSPECTION AND RETRIEVAL ACTIVITIES...............................................6-1

6.1. INITIAL CONTAINER INSPECTION ................................................... 6-1

6.2. HANDLING CONTAINER DOSE/SHIELDING

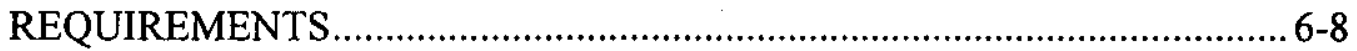

6.3. RETRIEVAL OF CONTAINERS TO INSPECTION/LAY-DOWN

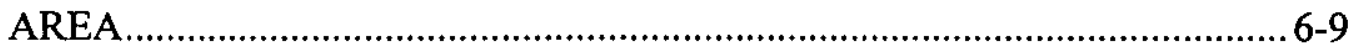

6.4. DRUM INSPECTION ........................................................................ 6-13

6.5. RETRIEVAL OF CONTAINERS WITH QUESTIONABLE INTEGRITY 
7.0 NDA AND DISPOSITIONING OF DRUMS ……............................................ 7-1

7.1. STAGING OF DRUMS FOR NDA ……...............................................

7.2. NDA AND PARTITIONING OF TRU/LLW DRUMS ……....................... 7-2

7.3. RE-INTERMENT OF LLW DRUMS ………...................................... 7-3

7.4. PREPARATION/STAGING OF TRU DRUMS FOR SHIPMENT …........... 7-4

8.0 DRUM VENTING ................................................................................................... 8-1

8.1. STAGING OF DRUMS FOR VENTING ……........................................ 8-1

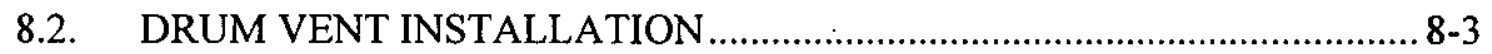

8.3. RESTAGING OF VENTED DRUMS .................................................. 8-6

9.0 DOCUMENTATION...............................................................................................9-1

9.1. HISTORICAL RECORDS ….............................................................. 9-1

9.2. DOCUMENTATION OF DATA COLLECTED DURING PHASE I

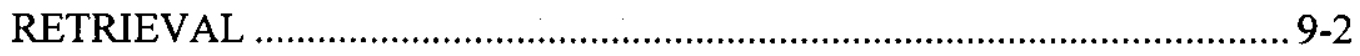

10.0 SPECIAL PROCESSING ISSUES …….....................................................10-1

10.1. CLASSIFIED WASTE …………………............................................

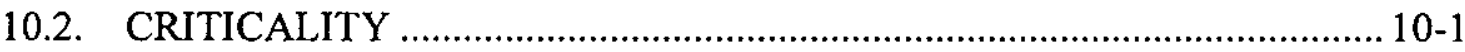

10.3. HORIZONTALLY-STORED DRUMS ……....................................... 10-3

10.4. "V" TRENCH DRUMS ........................................................................

10.5. WASTE CONTAINERS REQUIRING SPECIAL HANDLING ................. 10-5

10.6. VISIBLY OVER-PRESSURIZED CONTAINERS ................................. 10-7

10.7. ODD-SHAPED CONTAINERS............................................................

11.0 REFERENCES............................................................................................11-1 


\section{LIST OF TABLES}

TABLE 1-1. UNCERTAINTIES, ASSUMPTIONS AND RISKS ............................. 1-4 TABLE 10-1. CRITICALITY SAFETY EVALUATION REPORTS (CSERS) IMPACTED BY TRU RETRIEVAL ACTIVITIES ......................................... 10-2

\section{LIST OF FIGURES}

FIGURE 2-1. CONCRETE LINED V-TRENCH USED FOR TRANSURANIC

WASTE STORAGE

FIGURE 2-2. TRANSURANIC ASPHALT SLAB TRENCH …...............................2-4

FIGURE 3-1. HANFORD TRU RETRIEVAL FLOW DIAGRAM............................ 3-3

FIGURE 6-1. CONTAINER RETRIEVAL DATA FORM …...................................... 6-2 


\section{ACRONYMS AND ABBREVIATIONS}

\begin{tabular}{|c|c|}
\hline $\mathrm{AEC}$ & U. S. Atomic Energy Commission \\
\hline ALARA & As Low As Reasonably Achievable \\
\hline $\mathrm{CH}$ & Contact Handled \\
\hline CSER & Criticality Safety Evaluation Report \\
\hline CVS & Container Venting System \\
\hline $\mathrm{CWC}$ & Central Waste Complex \\
\hline DOE & U.S. Department of Energy \\
\hline DOT & U. S. Department of Transportation \\
\hline FGE & Fissile Gram Equivalents \\
\hline FRP & Fiberglass Reinforced Plywood \\
\hline FSAR & Final Safety Analysis Report \\
\hline GPR & Ground Penetrating Radar \\
\hline HPT & Health Physics Technician \\
\hline HWOP & Hazardous Work Operations Plan/Procedure \\
\hline ISB & Interim Safety Basis \\
\hline LANL & Los Alamos National Laboratory \\
\hline LEL & Lower Explosion Limit \\
\hline LLW & Low Level Waste \\
\hline NDA & Non-Destructive Assay \\
\hline NDE & Non-Destructive Examination \\
\hline NMED & New Mexico Environmental Department \\
\hline QA & Quality Assurance \\
\hline $\mathrm{QC}$ & Quality Control \\
\hline $\mathrm{PE}$ & Plutonium Equivalent \\
\hline PPE & Personnel Protective Equipment \\
\hline $\mathrm{RCO}$ & Radiological Control Organization \\
\hline RCRA & Resource Conservation and Recovery Act of 1976 \\
\hline RCT & Radiological Control Technician \\
\hline RL & DOE Richland Operations Office \\
\hline RWP & Radiological Work Permit \\
\hline SAR & Safety Analysis Report \\
\hline SARP & Safety Analysis Report for Packaging \\
\hline SRS & Savannah River Site \\
\hline SWBG & Solid Waste Burial Ground \\
\hline SWMF & Solid Waste Management Facility (SRS) \\
\hline SWITS & Solid Waste Information Tracking System [database] \\
\hline TPA & $\begin{array}{l}\text { Tri-Party Agreement (Hanford Federal Facility Agreement and } \\
\text { Consent Order) }\end{array}$ \\
\hline TRU & Transuranic [Waste] \\
\hline TRUM & Transuranic Mixed [Waste] \\
\hline TRUSAF & Transuranic Storage and Assay Facility \\
\hline TWISP & Transuranic Waste Inspectable Storage Project (LANL) \\
\hline USQ & Unreviewed Safety Question \\
\hline USQD & Unreviewed Safety Question Determination \\
\hline
\end{tabular}


HNF-5597

WIPP

Waste Isolation Pilot Plant

WRAP

Waste Receiving and Processing Plant 


\subsection{INTRODUCTION}

This document presents a process description for the retrieval of earth-covered, contacthandled $(\mathrm{CH})$, TRU waste drums located in the SWBG. This process will be used to meet the M-91-07 milestones for Phase I TRU retrieval and to provide data for Phase II TRU retrieval.

\subsection{PURPOSE}

The purpose of this document is to describe the process and operational options considered for compliant retrieval of the contact-handled $(\mathrm{CH})$ suspect transuranic (TRU) waste containers currently stored below grade in earth-covered trenches at the Hanford Site. This TRU retrieval process description will become the basis for the safety analysis that will be used to update the existing safety authorization basis for the Solid Waste Burial Grounds (SWBG).

The generation of a Safety Assessment for TRU Retrieval, which will be an addendum to the SWBG Safety Authorization Basis, will be required to authorize the retrieval of buried CH-TRU waste at Hanford. Presently, the SWBG Interim Safety Basis (ISB) (Bushore, 1998) does not allow for the excavation of buried TRU drums as one of the ongoing operations at the SWBG. Upon completion of this process description, an Unreviewed Safety Question Determination (USQD) will be performed for the activities and operations described. Activities that are determined to fall outside the current safety authorization basis will be analyzed to support the safety assessment.

\subsection{OBJECTIVE}

The goal of this effort is to develop a retrieval process that will handle a high percentage of the buried 55-gallon drums of CH-TRU waste that are to be retrieved from the SWBG. Further, the process is designed to allow for evaluation of specialized conditions on a case-by-case basis.

\subsection{SCOPE}

This process description discusses the following processes and options for retrieval:

- Excavation,

- Container Retrieval,

- Venting,

- Non-Destructive Assay (NDA),

- Criticality Avoidance,
- Incidental Waste Handling,

- Site Preparation,

- Equipment,

- Shipping.

Specific items that are addressed in this process description document include: 
- Unearthing drums in Burial Ground 218-W-4C (all trenches containing TRU drums), and Burial Ground 218-W-4B, Trench 7, and TV-7. The difficulties of retrieving drums in the TV-7 module are evaluated.

- The NDA of drums containing less than 1 gram of TRU. This assay will determine if the waste container contains less than $100 \mathrm{nCi} / \mathrm{g}$ and should be redesignated as LLW.

- The methodologies to be used for the handling of breached drums or structurally suspect containers.

- Interfaces with safeguards and security required to develop operational measures for handling classified waste.

- Handling of unvented drums. Options including venting within the trench as well as overpacking the drum in an $\mathrm{N}-55$ overpack and shipping to a treatment facility for venting are discussed. The process description provides a basis for determining if further analysis is required in the safety assessment.

- The layout for the work area, which includes consideration of other trenches within the burial ground where retrieval is taking place. The process description includes the work area layout, spoil pile placement, and staging areas for all retrieved waste containers.

- Development of a staging area for drum shipments. Drums that are determined to be TRU will be shipped to the Central Waste Complex (CWC) for storage, and low-level waste (LLW) drums will be re-interred within the burial ground. The TRU waste must be staged in an arrangement favorable for criticality prevention and security.

- Process equipment needed to perform the retrieval. The process description allows the use of various pieces of heavy equipment for earth removal. The equipment selected is capable of relocating large containers out of the work area.

This TRU waste retrieval process description is focused to take advantage of existing Los Alamos National Laboratory (LANL) TRU Waste Inspectable Storage Project (TWISP) documentation as well as additional TRU retrieval documentation from the Savannah River Site (SRS). Both of these Department of Energy (DOE) sites have recently retrieved stored, stacked CH-TRU drums (1997 to present). The LANL Final Safety Analysis Report (FSAR) and subsequent authorization basis changes are used as the base documents in support of Hanford TRU process description and retrieval options. 


\subsection{METHODOLOGY}

This process description discusses the unit operations associated with the following process segments:

- Pre-Start Activities (Chapter 4)

- Excavation (Chapter 5)

- Inspection and Retrieval (Chapter 6)

- Drum Venting (Chapter 8)

- Documentation (Chapter 9)

- Special Processing Issues (Chapter 10)

- NDA and Final Drum Disposition (Chapter 7)

To the extent practical, unit operations within these process segments were developed by considering current SWBG practices and operations as well as lessons learned from the TRU retrieval operations at SRS and LANL. Within each section, the selected process description for a given operation is followed by brief discussions of:

- Current SWBG procedures and practices,

- The approaches used for the Pilot TRU Retrieval and TRU Relocation Projects at Hanford,

- The process used for TRU retrieval operations at LANL, and

- The process used for TRU retricval operations at SRS.

When several equally viable alternatives exist, each of the process options is presented.

Chapter 2 provides the background information needed to put the process description chapters into context. Chapter 2 discusses the following topics:

- TRU Retrievable Storage in the SWBG

- Current Plans for the Retrieval of TRU Waste at Hanford

- Previous TRU Retrieval Experience at Hanford, LANL, and SRS

- The SWBG Safety Authorization Basis

\subsection{UNCERTAINTIES AND ASSUMPTIONS}

Table 1-1 lists the uncertainties associated with this process description along with the enabling assumptions developed to address each uncertainty. The final two columns of Table 1-1 provide an assessment of the risk associated with each assumption and the action(s) required either to validate the assumption or to mitigate the risk posed by it. 
Table 1-1. Uncertainties, Assumptions and Risks

\begin{tabular}{|c|c|c|c|}
\hline Uncertainty & $\begin{array}{c}\text { Enabling } \\
\text { Assumption }\end{array}$ & Risk & $\begin{array}{l}\text { Validation or } \\
\text { Mitigation }\end{array}$ \\
\hline $\begin{array}{l}\text { Waste acceptance } \\
\text { criteria for facilities } \\
\text { potentially receiving } \\
\text { TRU drums have } \\
\text { not been } \\
\text { established. }\end{array}$ & $\begin{array}{l}\text { When established, } \\
\text { waste acceptance } \\
\text { criteria will not affect } \\
\text { the retrieval operations } \\
\text { described herein. }\end{array}$ & $\begin{array}{l}\text { Waste acceptance } \\
\text { criteria will impose } \\
\text { functional } \\
\text { requirements for } \\
\text { retrieval that have not } \\
\text { been addressed in this } \\
\text { process description. }\end{array}$ & $\begin{array}{l}\text { Waste acceptance } \\
\text { criteria are currently } \\
\text { being developed. As } \\
\text { early as practicable } \\
\text { they will be compared } \\
\text { to the process } \\
\text { described herein. }\end{array}$ \\
\hline $\begin{array}{l}\text { Number of TRU } \\
\text { drums that will be } \\
\text { retrieved from the } \\
\text { SWBG and the } \\
\text { number that will } \\
\text { assay as LLW and } \\
\text { remain disposed. }\end{array}$ & $\begin{array}{l}\text { Approximately } 50 \% \text { of } \\
\text { the suspect-TRU } \\
\text { containers in the } \\
\text { SWBG will assay as } \\
\text { LLW. }\end{array}$ & $\begin{array}{l}\text { Insufficient storage/ } \\
\text { treatment capacity for } \\
\text { retrieved containers. }\end{array}$ & $\begin{array}{l}\text { Early retrieval } \\
\text { experience in concert } \\
\text { with a review of } \\
\text { historical records }\end{array}$ \\
\hline $\begin{array}{l}\text { Number of TRU } \\
\text { drums that are } \\
\text { unvented. }\end{array}$ & $\begin{array}{l}\text { For drums buried after } \\
1978, \text { less than } 5 \% \text { of } \\
\text { the TRU drums will } \\
\text { require venting. } \\
\text { Virtually all of the } \\
\text { TRU drums buried in } \\
1978 \text { or before will } \\
\text { need to have vents } \\
\text { installed. }\end{array}$ & $\begin{array}{l}\text { The number of pre- } \\
1979 \text { drums that } \\
\text { require venting may be } \\
\text { higher than expected }\end{array}$ & $\begin{array}{l}\text { This process } \\
\text { description includes } \\
\text { the options of venting } \\
\text { drums at T Plant or, if } \\
\text { needed, in the SWBG. }\end{array}$ \\
\hline $\begin{array}{l}\text { The integrity of } \\
\text { containers to be } \\
\text { retrieved or } \\
\text { relocated. }\end{array}$ & $\begin{array}{l}\text { Visual inspection will } \\
\text { adequately determine } \\
\text { container integrity for } \\
\text { the purposes of } \\
\text { retrieval or relocation. }\end{array}$ & $\begin{array}{l}\text { Visual inspection may } \\
\text { miss wall thinning and } \\
\text { other microscopic } \\
\text { defects. Subsequent } \\
\text { movement of a } \\
\text { defective drum with } \\
\text { unidentified } \\
\text { weaknesses may lead } \\
\text { to a release of } \\
\text { contaminants. }\end{array}$ & $\begin{array}{l}\text { TRU retrieval at both } \\
\text { LANL and SRS relied } \\
\text { on visual inspection to } \\
\text { determine container } \\
\text { integrity. No releases } \\
\text { were recorded as a } \\
\text { result of breaches } \\
\text { missed in the visual } \\
\text { inspection. }\end{array}$ \\
\hline $\begin{array}{l}\text { Equipment } \\
\text { availability for } \\
\text { retrieval activities }\end{array}$ & $\begin{array}{l}\text { Equipment called out } \\
\text { in this process } \\
\text { description is available } \\
\text { or can be obtained. }\end{array}$ & $\begin{array}{l}\text { Further safety analysis } \\
\text { may be required if } \\
\text { equipment that was not } \\
\text { specified in this } \\
\text { description is chosen. }\end{array}$ & $\begin{array}{l}\text { If several equipment } \\
\text { types will perform the } \\
\text { tasks outlined in this } \\
\text { process description, all } \\
\text { are included. }\end{array}$ \\
\hline
\end{tabular}




\subsection{BACKGROUND}

The Hanford Site is one of ten DOE sites that generate and/or store TRU wastes generated by national defense programs. In 1970, the U. S. Atomic Energy Commission (AEC) defined TRU waste as a separate waste category and declared that it must be stored in a form that is retrievable as contamination-free packages designed to last 20 years, pending decisions on permanent disposal (AEC, 1970). Since 1970, approximately 37,400 suspect-TRU and mixed-TRU (TRUM) waste containers have been placed in retrievable storage at the Hanford Site.

The majority of CH-TRU waste drums at Hanford (approximately 26,200) are stacked vertically on asphalt pads in earth-covered trenches in the SWBG. These drums will be retrieved, visually checked for structural integrity, and, if necessary, placed in an overpack container. If the records indicate that the TRU content of the container is less than 1 gram, the container will be non-destructively assayed to determine if the waste is TRU or Low Level Waste (LLW).

The LLW containers will remain disposed of in the SWBG, and the TRU waste drums will be transported from the burial ground to a Treatment, Storage or Disposal (TSD) facility where they will be staged prior to being accepted into Hanford's Waste Isolation Pilot Plant (WIPP) Certification Program. A small percentage of TRU drums are expected to require special handling that would preclude their retrieval from the SWBG during the Phase I Retrieval Project. These drums as well as TRU waste containers other than drums will remain in the SWBG pending disposition at a later date.

\subsection{TRU RETRIEVABLE STORAGE IN SWBG TRENCHES}

In order to implement the new TRU waste management requirements from the AEC (AEC, 1970), the storage of TRU waste in below-grade trenches in the Hanford Site 200 Areas was begun in 1970. Many of these trenches were also used for the disposal of LLW containers. Appendix A contains a general overview of the number and types of containers of suspect-TRU waste currently stored in SWBG trenches.

The TRU storage trenches were built with several physical configurations, depending on the time period. The sections below discuss the basic trench types that will be encountered during TRU retrieval (from Duncan, 1995). This process description is limited to the retrieval of TRU waste drums from the asphalt-base trenches in burial Grounds 218W-4B and 218W-4C and the concrete " $V$ " trench in Burial Grounds 218W4B. A discussion of TRU storage in the caissons, which are also TRU storage units within the SWBG trenches, is outside the scope of this document. 


\subsubsection{HORIZONTAL STACKING}

The first storage configuration, used from 1970 to 1972, consisted of several layers of containers stacked horizontally in a gravel bottom " $\mathrm{V}$ " trench. The containers were

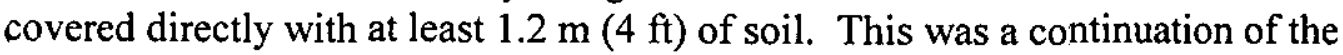
previously unsegregated waste storage configuration (pre-1970). This configuration provided for the minimum space usage to waste volume ratio at a minimum cost.

\subsubsection{CONCRETE V-TRENCH}

In June 1972, a prototype V-trench became operational for the interim storage of 55 gallon drums containing TRU waste (see Figure 2-1). This trench was constructed as a 90-degree $\mathrm{V}$-shaped concrete slab. The cross section is essentially square but oriented with corners at the bottom and top. When filled with drums, it was enclosed with a

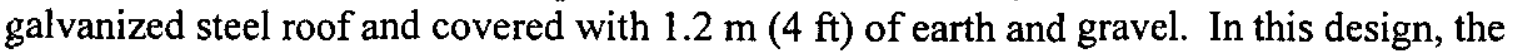
drums were separated from soil and moisture to reduce corrosion during storage. The structure was designed to contain possible leakage from drums within the structure.

Divided into four compartments, the V-trench is $30 \mathrm{~m}$ (100 ft) long and has a storage capacity of about 1,400 drums. The portable metal cover was provided to exclude sand, moisture, and debris from the drum configuration. The concrete structure provided a base for the pile of drums to isolate them from the ground. The slope of the decking was designed to drain any moisture away from the trench.

\subsubsection{PLYWOOD BASE}

The third configuration consisted of a wide bottom and V-trench. In both cases, the trench floor was covered with plywood and drums were stacked vertically. Fire-retardant plywood was placed between layers of drums and on top of the drums. Drum stacks were separated into modules, each module a 12 by 12 array 4 to 5 drums high. Each module was completely covered by a plastic tarp and separated from the next module by several feet of earth. Vent pipes of 5-cm (2-in.) polyvinyl chloride piping were placed in the middle of each module from the trench bottom to 1 to $2 \mathrm{~m}(3.3$ to $6.6 \mathrm{ft})$ above the soil surface in an attempt to reduce humidity. This storage configuration was used in the 200 West burial grounds 218W-3A and 218W-4B from 1974 until 1988.

\subsubsection{ASPHALT BASE}

This configuration, shown in Figure 2-2, consists of wide-bottom trenches and is similar to the third with the exception of asphalt base rather than plywood. This trench type was used in 218W-4B Trench 7 from 1974 until 1980 and in 218W-4C from 1978 until 1988. 


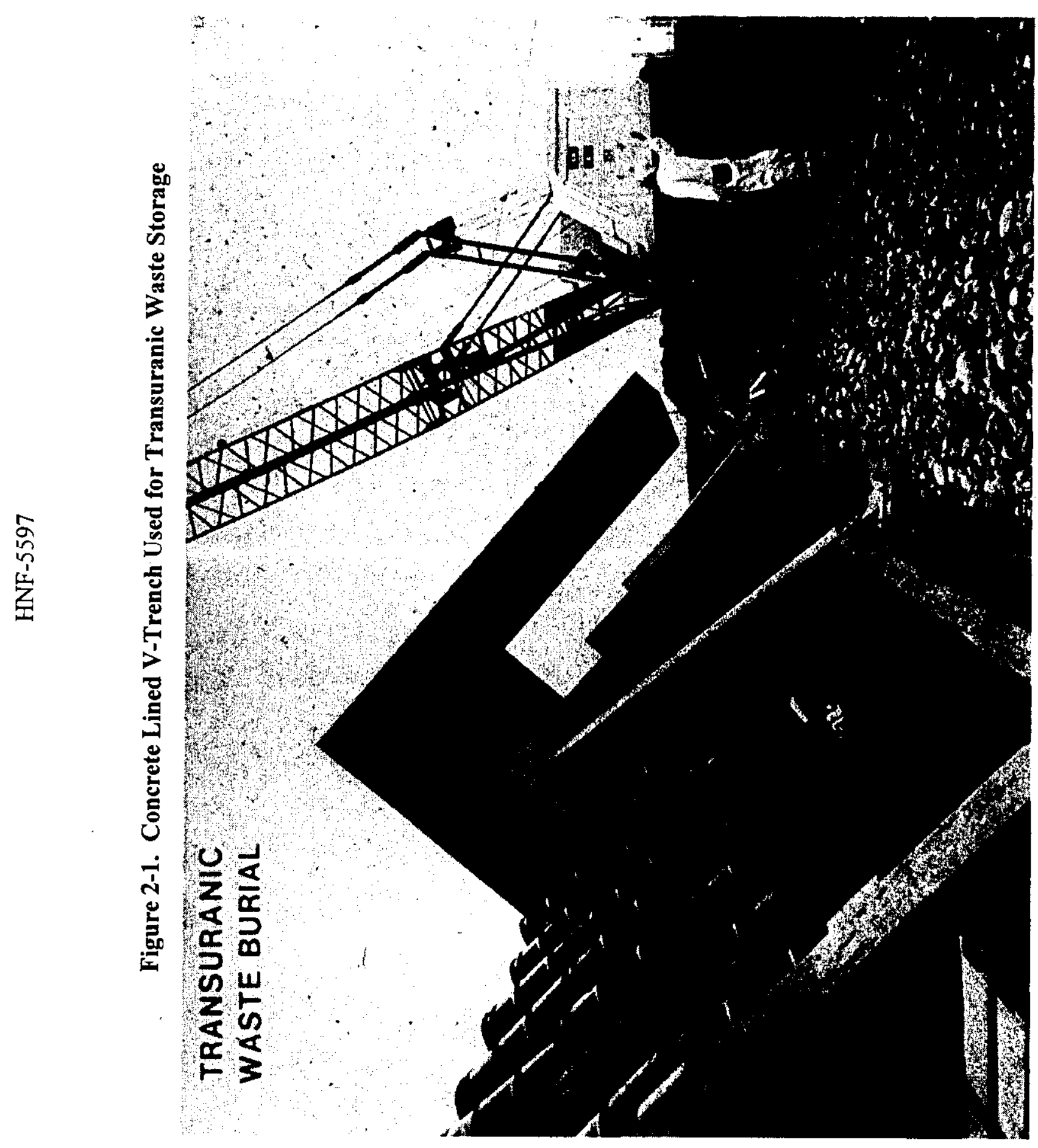

ஸे 


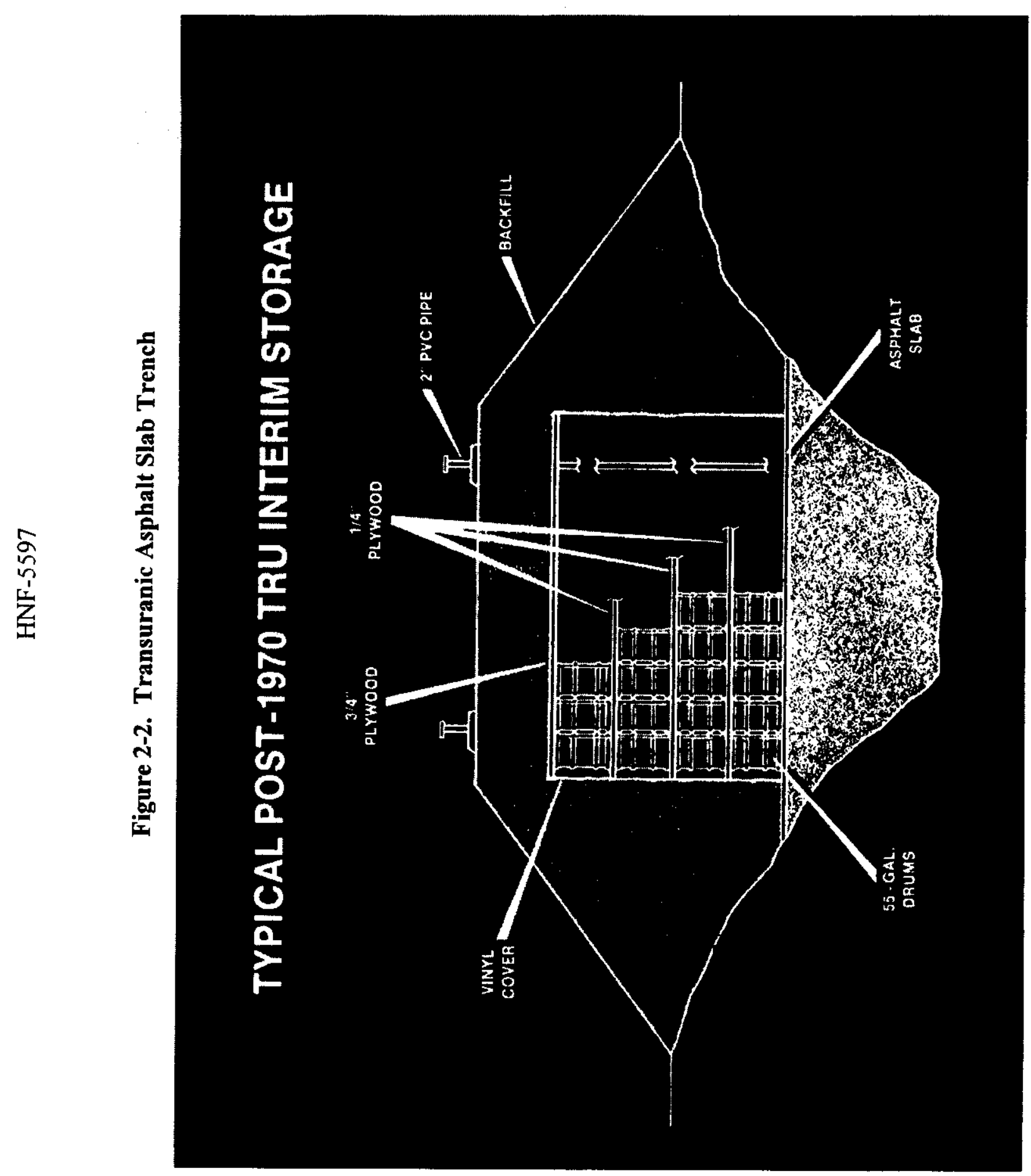

$\stackrel{+}{i}$ 


\subsection{TRU WASTE RETRIEVAL PLANS AT HANFORD}

The retrieval of TRU waste at Hanford is broken down into two separate planning efforts, which are referred to as Phase I and Phase II retrieval. Phase I retrieval, which was originally to have been accomplished by Project W-113, is planned to retrieve approximately 10,000 55-gallon drums of CH-TRU waste, primarily from Burial Ground 218W-4C. Phase I retrieval to meet the M-91-04 milestone was initiated in August 1999 and is scheduled for completion by September 2004. Phase II retrieval, which is scheduled to commence in FY 2006, will retrieve the remainder of the TRU waste from the SWBG.

\subsubsection{Phase I Retrieval}

The Hanford Federal Facility Agreement and Consent Order, which is also referred to as the Tri-Party Agreement (TPA) (Ecology, et al., 1989), has several milestones associated with the retrieval of post-1970 TRU wastes from the SWBG. Tri-Party Agreement milestone M-91-04 requires that the DOE "complete construction of small container contact handled (CH) TRU/TRUM retrieval facility(s) and initiate retrieval of small container TRU/TRUM from 200 Area burial grounds" by September 30, 2000. Additionally, M-91-07 requires that the DOE "complete Project $W-113$ for post-1970 CH TRU/TRUM retrieval." by September 30, 2004. The retrieval activities encompassed by these two milestones are commonly referred to as Phase I retrieval.

The Transuranic (TRU) Waste Phase I Retrieval Plan (McDonald, 1999) describes the activities associated with the assessment of approximately 10,000 suspect TRU drums located in burial ground $218-\mathrm{W}-4 \mathrm{C}$ and the retrieval of those drums confirmed to contain TRU waste. The 55-gallon suspect-TRU drums will be retrieved, checked for structural integrity, overpacked if necessary, and assayed to determine if the drum is LLW $(<100$ $\mathrm{nCi} / \mathrm{g}$ ) and can remain disposed of in the SWBG. TRU waste will be retrieved from the burial ground and stored at the CWC pending processing and certification through the WIPP Certification Program.

\subsubsection{Phase 2 Retrieval}

Phase 2 retrieval will involve retrieval of the entire inventory of retrievably stored, remote- and contact-handled TRU waste less the total retrieved during Phase I and the alpha caisson retrieval. Phase 2 will be confined to trenches in the SWBG. The container integrity for the waste that will be retrieved is expected to range from completely sound to substantially degraded. 


\subsection{PREVIOUS TRU RETRIEVAL EXPERIENCE}

Planning for large-scale retrieval of the contact-handled TRU wastes stored at DOE sites began in the late 1980s in an effort to comply with newly mandated state and federal regulations. In all cases, very costly projects were originally envisioned to accomplish the necessary TRU retrieval activities. Over the last five years (1994-1999), CH TRU waste retrieval has been conducted at Hanford, LANL, and SRS. Each of these three sites had different drivers to begin retrieval. The following sections provide a brief overview of these retrieval activities.

\subsubsection{Pilot Retrieval Project at Hanford}

Planning for the retrieval of TRU drums from the SWBG at Hanford was begun in 1988. The original planning document (Anderson, 1989) defined the scope and developed a plan to provide the information and methodology required to work-off retrievably stored Hanford wastes. The document divided the program into three parts:

- Part I, an existing records study;

- Part II, a TRU drum pilot retrieval and container inspection project that would include nondestructive examination (NDE) and nondestructive assay; and

- Part III, a glovebox examination of the retrieved wastes to determine and characterize container contents.

The Part I document (Anderson, 1991), which was originally completed in May 1988, evaluated historical data for CH-TRU drums from Hanford waste records. The Part II document (Anderson and Duncan, 1989) described nineteen "sampling sites" selected to examine unique waste storage configurations and retrieve waste containers from among the entire inventory of Hanford stored TRU waste containers. The selection of sampling sites was based on the waste storage configuration. The program was designed to collect the waste characterization data necessary to plan full-scale TRU retrieval at Hanford as well as to provide information necessary to support WRAP facility design.

Part II, the Pilot Retrieval Project, was divided into two projects, which were governed by two separate safety analysis reports (SARs). One SAR (Joyce and Harker, 1993) was developed for the inspection and retrieval of vented drums (first five sites), while a proposed second SAR was to cover unvented container inspection and retrieval at the remaining fourteen sites. This division was made because of the postulated increased potential of hydrogen in the unvented and the possibility of drum explosions, resultant fire, and radionuclide release.

An additional Part II task was the development, fabrication, and testing of a container venting system to vent unvented containers (i.e., those without a Hanford vent clip) that 
were placed in 20-year retrievable storage before 1978. The Container Venting System (CVS) was developed at Hanford to fulfill this purpose.

Hanford was the only DOE Site to vent drums (using the Hanford-developed vent clip)

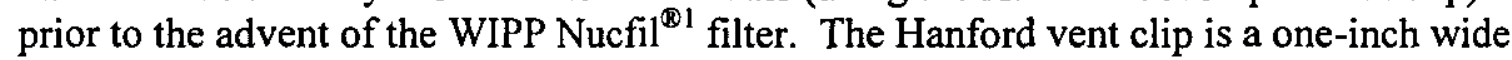
strip of metal (26 gage stainless steel) bent to fit over the drum so the lid gasket would be compressed and not make a complete seal to the drum when tightened in place. The gap in the lid gasket allowed generated gases to escape the drum while retaining particulate radionuclides. The vent clips were installed on all TRU waste drums generated at Hanford by 1979. Shipments of offsite drums equipped with vent clips were first documented as being received in 1980 (Duncan, 1995).

In an initial Part III document (Demiter, 1988), facilities were identified for waste container opening, waste sorting, and waste characterization. The Part III program was discontinued in 1991 with the expectation that the Waste Receiving and Processing (WRAP) facility would conduct all waste container opening, sorting, and characterization required to meet WIPP waste acceptance criteria.

The SAR for the Pilot TRU Drum Retrieval Project, which placed many restrictions on the project that affected work methods and development, became the over-riding element of the vented TRU Drum Retrieval Project. Procedures, Hazardous Waste Operating Permit (HWOP), soil sampling plan, training plan, and many other draft documents were prepared based on the SAR requirements. Ultimately, drums were retrieved from the first two sites only. The most recent drums from these sites were placed in the burial grounds between 1980 and 1982.

\subsubsection{TRU Relocation Project at Hanford}

In 1996 and 1997, approximately 500 drums identified as $\mathrm{CH}$-TRU were relocated from uncovered drum modules in Burial Ground $4 \mathrm{C}$ of the SWBG into covered facilities within the CWC (Irwin, 1997). The retrieval process for these drums included NDA to confirm the TRU designation. This project was done under the current safety authorization basis for the SWBG (see Section 2.4).

\subsubsection{Los Alamos National Laboratory}

Between 1970 and 1988, LANL placed 16,600 drums in 20-year retrievable storage on TRU pads 1,2 , and 4 . All drums were unvented. The drums were mainly 55 -gallon drums that had a rigid 90-mil polyethylene liner placed inside the drum. The top of the liner either was snapped or screwed on. The liner was used to protect the inner surface of the drum from the waste form.

\footnotetext{
${ }^{1}$ Nucfil is a registered trademark of Nuclear Filter Technology, Inc.
} 
The TRU storage pads provided ground-level storage on asphalt. Drums were stacked four and five high, usually surrounded by fiberglass-reinforced plywood (FRP) or metal boxes, and covered with four feet of earth. The covered TRU pads were mounded above ground level, unlike the below grade asphalt pad storage at Hanford.

The LANL TRU storage pads are classified differently from those at Hanford. When the Resource Conservation and Recovery Act (RCRA) Part A and Interim Part B permits were submitted to the New Mexico Environmental Department (NMED) in 1988, the TRU drums in 20-year retrievable storage were described as being in an active storage configuration. Therefore, the LANL retrievably stored drums as well as any associated activities to retrieve the drums after 1988 were governed by appropriate RCRA regulations.

In 1989, as retrieval activities at DOE sites began to increase, LANL indicated that technology developed by other DOE sites would be applied to the retrieval of stored TRU wastes from pads 1,2, and 4 . Hanford became the lead site in the development of drum venting and the preparation of documentation required for the retrieval of TRU drums. LANL followed the retrieval progress of other sites and developed a generic TRU program. In 1992, LANL decided to conduct a small sampling of TRU drums stored on pad 2, and sixteen (16) drums were retrieved in April of that year.

The LANL contact-handled retrieval project is known as the Transuranic Waste Inspectable Storage Project (TWISP). The title of the project indicates that the wastes are to be retrieved and placed in inspectable storage, but that no processing of the wastes is to be conducted. The scheduled TRU retrieval activities supported the following milestone completion dates:

- Retrieve 4,880 unvented drums and 161 FRP boxes from TRU pad \#1 by September 30, 1998.

- Retrieve 4,540 unvented drums and 51 FRP boxes from TRU pad \#4 by September 30, 2000.

- Retrieve 7,000 unvented drums from pad \#2 by September 30, 2003.

The schedule also included milestones to wash and vent drums and to place them in inspectable RCRA storage.

\subsubsection{Savannah River Site}

SRS began segregating TRU wastes from other radioactive wastes in 1970 following Atomic Energy Commission (AEC) Immediate Action Directive 0511-21 (AEC, 1970). The TRU wastes at SRS were further separated by placing $<0.5$ curie wastes on earthen storage pads and $>0.5$ curie wastes in metal culverts or caissons (called casks at LANL). 
This was done because most of the retrievably stored TRU wastes at SRS are Pu-238, unlike LANL and Hanford TRU wastes which contain primarily Pu-239.

As at LANL, the SRS TRU drums stored on pads were unvented. SRS drums also had a rigid 90-mil polyethylene liner placed inside the drum. The polyethylene liner was in two parts that either screwed or snapped together. The liner was to provide protection to the drum inner surface from waste forms.

The practice of storing unvented TRU wastes drums on earth-covered pads continued until 1985. After 1985, TRU drums were vented using the WIPP Nucfil ${ }^{\circledR}$ filter, and placed outdoors on concrete Pads 7 through 13. Over the years, the vented drums collected water through the vent filter. The drums were radiographed, dewatered, and removed to covered storage during the early 1990s.

The remaining 8,810 unvented drums under earthen cover on TRU Pads 2 through 6 became the focus of the SRS TRU program. Like LANL and Hanford, SRS had conducted several activities to assess the drum conditions. SRS had buried metal coupons early in the TRU program, and corrosion data was taken at intervals. When compared to LANL and Hanford, drums buried at the SRS site showed accelerated corrosion due to the abundant rainfall and more acidic soil (Kriikku, 1991).

Between FY 1988 and FY 1994, SRS developed several programs to focus on remote handling, characterization, and the processing of retrieved wastes. SRS also worked with LANL to develop a lancet drill bit/filter assembly to drill through the unvented drum lids and 90-mil polyethylene liners. The hollow lancet would also pull a drum head-gas and liner gas sample in the same manner as the Hanford CVS. When the TRU funding from DOE-HQ dropped in 1995, most of these programs ended.

\subsection{SWBG SAFETY AUTHORIZATION BASIS}

The current safety authorization basis for the SWBG consists of the following documents:

- HNF-SD-WM-ISB-002, Solid Waste Burial Grounds Interim Safety Basis (Bushore, 1998)

- HNF-SD-WM-TSR-001, Solid Waste Burial Grounds Interim Operational Safety Requirements (WHC, 1995a)

- HNF-SD-WM-SARR-028, Solid Waste Burial Grounds Interim Safety Analysis (WHC, 1995b)

- WHC-SD-WM-SAR-058, Final Safety Analysis for Contact-Handled Transuranic Waste Drum In-Situ Inspection and Vented Drum Retrieval (Joyce and Harker, 1993) 
Because the activities planned for the retrieval of uncovered drums constitute standard activities for the SWBG, the SWBG safety basis currently allows retrieval of the approximately 1500 drums that do not require excavation. Modifications to the SWBG safety authorization basis are required, however, prior to the excavation of buried drums. The SWBG ISB currently states that "Retrieval of buried TRU waste beyond the vented drums as analyzed in [WHC-SD-WM-SAR-058] will require approval of additional safety analyses that revise the Solid Waste Burial Ground authorization basis." In addition, the SWBG safety basis does not currently address container venting operations, and a safety analysis evaluating the venting operation and identifying any operational limitations will have to be approved by DOE prior to initiating this activity.

Movement of the retrieved drums from the SWBG to another TSD facility will also require coverage under the safety authorization bases for the SWBG and the receiving TSD facility or under a Safety Analysis Report for Packaging (SARP). Two (SARPs) for steel drums are currently in place. The SARP for 55 gallon drums (McCormick, 1998) has been recently updated, but is quite restrictive on TRU payloads. A revision (unrelated to the TRU retrieval effort) is currently being prepared to reevaluate many of these restrictions. A separate effort is being pursued to evaluate the existing 55 gallon SARP and the 85 gallon drum SARP (Stevens, 1994) to assure an approved safety authorization basis for the packaging activities associated with the TRU retrieval effort. This effort will include evaluation of the following items:

- Minor changes to the lifting requirements to allow greater operational flexibility

- Methodology required for shipping unvented drums to T-Plant if necessary

- New tie-down analysis and potential use of stake-bed trucks

- Movement of unvented drums 
HNF-5597

\subsection{PROCESS OVERVIEW}

This chapter provides a general overview of the process proposed for the retrieval of TRU drums from the SWBG. Subsequent chapters provide additional, specific details for each of the process steps.

\subsection{STRATEGY AND APPROACH}

This TRU Retrieval Process is designed such that the highest percentage of stored suspect TRU containers may be excavated, retrieved, inspected, and dispositioned to meet the milestones associated with TPA milestone M-91-07 for Phase I retrieval and the goals for Phase II retrieval planning. It is to be expected that some waste containers and waste forms will fall outside the envelope of this process description. Containers that require special handling will be dispositioned on a case-by-case basis.

The process description is described with sufficient latitude to allow prudent operational changes to be made in order to improve efficiency or safety while not impacting the prescribed safety envelope for a specific operation. As with all significant operations or activity changes, the USQ process will be followed for process changes that are believed to be outside the approved safety authorization basis.

\subsection{GENERAL PROCESS FLOW}

A general process overview for the retrieval of earth-covered TRU containers is given in Figure 3.1. The process flow steps and decision points shown in the figure provide a simplified understanding of the process.

Prior to performing field activities, historical records will be reviewed and applicable data recorded for each drum scheduled for retrieval. The initial field activity is site set-up and preparation. Retrieval and NDA equipment will be staged in or near the trench chosen for retrieval. Staging and work areas will be defined and set up. Background air monitoring of the retrieval site to meet safety and environmental requirements will be performed at this time.

The excavation of the trench module will be initiated following completion of site set-up and preparation. The overburden soil will be removed to expose the waste containers. Excavation equipment will be chosen to effectively remove soil and retrieve the waste containers. Stable trench wall slopes will be maintained to ensure compliance with site excavation requirements and to ensure confined spaces are not created. Excavation activities will be monitored to identify any contamination that may be present and to minimize impacts to worker health and safety. Any contaminated soils will be managed in accordance with applicable SWBG requirements and regulations. Uncontaminated soil will be placed in a spoil pile for reuse within the SWBG.

Prior to backfilling the trench during the initial burial of suspect-TRU containers, a tarp was placed over the top tier of containers. The tarp was then covered with a layer of plywood. When this cover is exposed, the plywood will be removed and managed appropriately. The tarp will be rolled back to expose the waste containers. 
The exposed containers will be inspected before actual retrieval. The visual inspection will verify container integrity and the presence of a Hanford vent-clip or a Nucfil ${ }^{\circledR}$ filter and identify the Package Identification Number (PIN). The containers will also be surveyed and smeared to identify potential contamination. Information regarding the individual containers will be recorded on applicable data sheets.

Containers with adequate integrity and dose readings within contact handling limits will be bar-coded and removed from the storage site. Containers other than a 30-gallon drum, 55-gallon drum, or 85gallon drum overpack will be removed, repackaged if necessary, and relocated within the disposal unit for later processing.

Contaminated drums will be wrapped, and overpacked as needed. Drums with questionable containment will be overpacked. Drums with waste records indicating TRU content exceeding 200 Fissile Gram Equivalents (FGE) will be removed from the process flow and relocated in accordance with applicable criticality specifications.

The drums with records indicating a TRU content less than $1 \mathrm{~g}$ will then be staged for NDA. Following $\mathrm{NDA}$, those drums that have assay values less than $100 \mathrm{nCi} / \mathrm{g}$ will be re-interred in the $\mathrm{SWBG}$ and the appropriate records will be updated. The drums with assay values exceeding $100 \mathrm{nCi} / \mathrm{g}$ will be vented if non-vented and then staged for shipment to a TSD unit on-site. Drums with records indicating a TRU content greater than 1 gram may bypass the NDA step and go directly to venting and/or staging for shipment. 


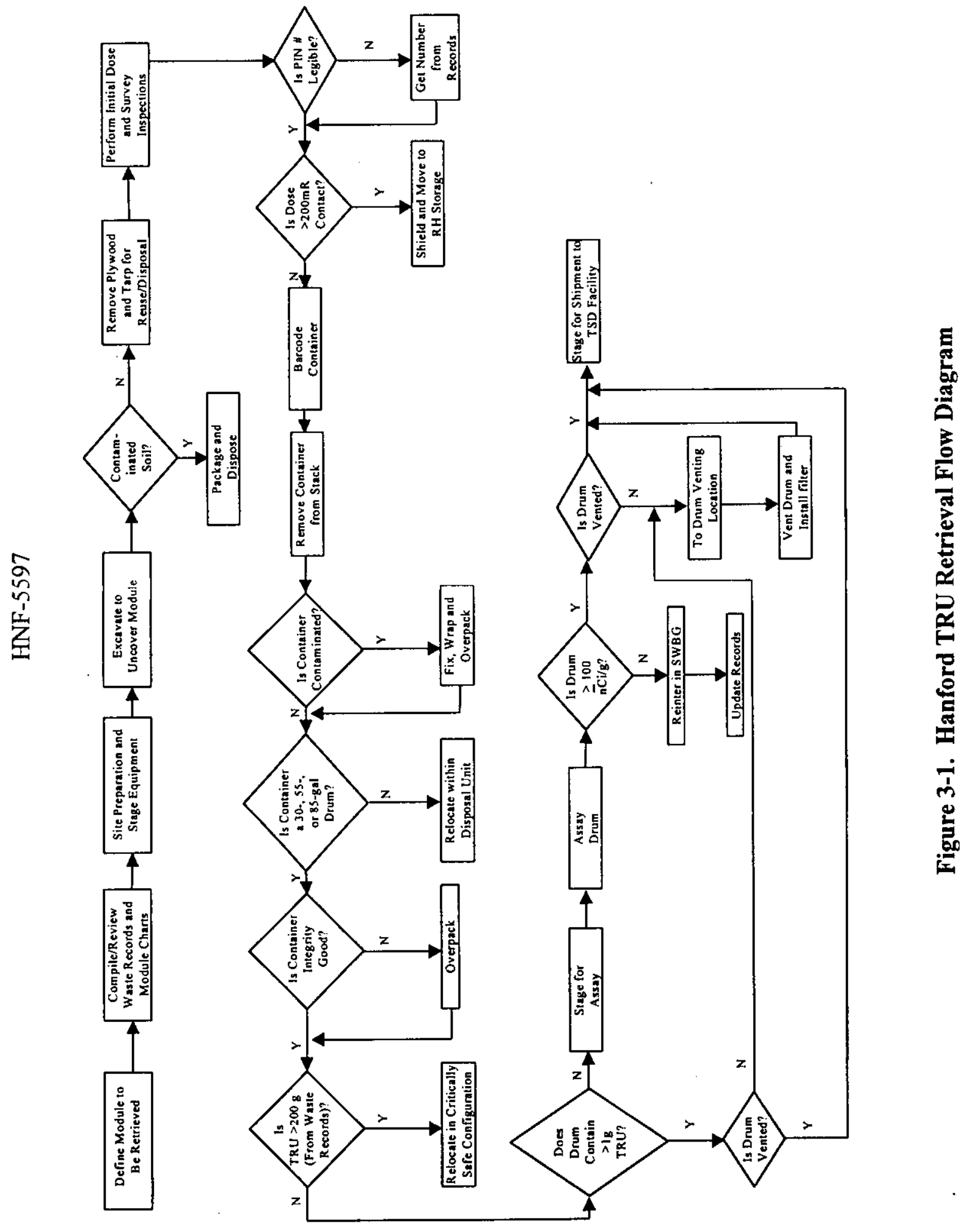

9 


\subsection{PRE-START ACTIVITIES}

The following pre-operational activities need to occur before excavation and retrieval of TRU waste containers begins:

- Records for drums to be retrieved will be reviewed. (Section 4.1)

- The retrieval site will be identified as appropriate (i.e., with fencing, roped area, and signs) and access control will be provided. General housekeeping and cleanup in the trench where retrieval is to occur will be conducted, including removal of tumbleweeds, drifted sand, etc. Module vent risers will be sampled to ascertain if combustible or organic gases are present.

Worker accommodations (change room, offices) will be provided and supplies will be staged as needed. Drum inspection areas (including radiological survey, visual check of drum integrity, and labeling), drum overpacking area, staging areas for drums awaiting assay, staging areas for TRU drums to be shipped, and staging areas for LLW prior to disposal will be identified and marked. (Section . 4.2)

- The mobile assay system will be set-up. (Section 4.3)

\subsection{RETRIEVAL OF HISTORICAL RECORDS}

Before physical retrieval of the waste, a review of existing waste records, similar to that done for the TRU drum relocate projects in FY96 and FY97 (Irwin, 1997), will be conducted. The reviewer will search available records such as the Solid Waste Information and Tracking System (SWITS) database, burial records, location maps, and supplemental generator records. The purpose of the records review is two-fold:

1. The review of historical records will allow the retrieval team to identify drums that pose potential additional hazards to workers or that require special handling. Examples include drums with high gram quantities of fissile material, drums with high dose rates, overweight drums, or drums from waste streams with high potential for containing hazards.

2. The records review will also facilitate division of the trench modules into waste streams with similar characteristics, should that be desired. For example, drums may be staged to facilitate the NDA operation, since it is anticipated that minimization of drum movement will be an important issue due to space constraints on the pad.

From the data obtained during the record review, Container Retrieval Data Forms will be prepared for the containers expected to be retrieved. The form will record pertinent drum 
data from SWITS and other historical records as well as data about the retrieved drum collected during the retrieval process. New data may include information such as drum number, weight, size, surface dose rate, retrieval date, drum condition, NDA results, and final disposition. Initially, these sheets will include the historical information listed below.

- container number

- size

- weight
- surface dose rate

- container position in the module

- TRU fissile content (grams)

Once the waste containers are re-disposed, relocated, or retrieved, data from the Container Retrieval Data Forms and bar-code scanners will be used to update the SWITS database.

\subsubsection{Current SWBG ISB Approach}

The documentation that accompanies newly generated waste packages accepted into the SWBG is reviewed as part of the acceptance process. This review is part of the process used to ensure wastes that might compromise the facility safety envelope are not accepted into the SWBG. The data from this documentation is subsequently entered into the SWITS database along with the waste container's disposal location in the SWBG.

The safety analysis for the SWBG makes extensive use of historical records to determine source terms and accident consequences.

\subsubsection{Pilot Retrieval SAR Approach}

The safety analysis for the TRU Pilot Retrieval Project made extensive use of historical records to determine source terms and accident consequences. Specific characteristics of the drums that were to have been retrieved under this project are documented in the SAR (Joyce and Harker, 1993).

\subsubsection{LANL Approach}

At LANL, a drum data form was filled out prior to inspecting the drums. The data form had original data from the LANL TRU Waste Database on the drums. The data on the form was confirmed at the retrieval face inspection. The form had the following data:

- Drum number

- Label number

- Drum size

- Contents description

- Weight
- Surface dose rate

- Possible $\mathrm{H}_{2}>$ Lower Flammability Level 
During the retrieval process, LANL also compared records with drums that had been removed from the stack, moved to the inspection area, and cleaned. When no data was found for a specific drum (whether lost or never recorded), the drum shipment data and best facility knowledge were used (Demiter, 1998).

\subsubsection{SRS Approach}

Data for the SRS drums is contained in the Computerized Burial Records Accounting (COBRA) database. The database contains limited information on the stored containers (isotopic distribution, generator, date shipped, date received, date placed, dose and specific drum number) as well as the location of a drum (given only by grid coordinates of the area). Therefore, specific location of the drum within the storage was not exactly known, only that it was somewhere in the given grid location. (Typically the grid was about a 25 -foot square.)

The information from the COBRA system was available to the inspection and retrieval crew, but was only used when a drum or container was found to be outside the general retrieval criteria and set aside for disposition.

\subsection{SITE SET-UP AND PREPARATION}

The retrieval site will be identified as appropriate (i.e., with fencing, roped area, and signs) and access control will be provided. Once the removal of any uncovered drums has been confirmed, general housekeeping and cleanup in the trench where retrieval is to occur will be conducted (i.e., removal of tumbleweeds, drifted sand, etc).

Drum inspection areas (including radiological survey, visual check of drum integrity, and labeling), drum overpacking area, staging areas for drums awaiting assay, staging areas for TRU drums to be shipped, and staging areas for LLW prior to disposal will be identified and marked.

An existing facility or a temporary building may be used to house supplies and to provide office space for retrieval team personnel. These facilities will be located as close to the retrieval site as practical. Supplies (e.g., barcode supplies, drum overpacks, shielding) will be staged as needed.

Historically, vent pipes of 5-cm (2-in.) polyvinyl chloride piping were placed in the middle of each module from the trench bottom and extend 1 to $2 \mathrm{~m}$ ( 3.3 to $6.6 \mathrm{ft})$ above the soil surface in an attempt to reduce humidity. Prior to commencing excavation activities, module vent risers may be sampled to ascertain if combustible or organic gases are present. 


\subsubsection{Current SWBG ISB Approach}

Retrieval of buried waste containers is not authorized under the SWBG ISB. However, retrieval of a limited number of buried drums is authorized under the Pilot Retrieval SAR (Joyce and Harker, 1993), which is included in the current safety authorization basis.

\subsubsection{Pilot Retrieval SAR Approach}

Site set-up and preparation steps for Pilot Retrieval were described in a detailed work plan that included operating procedures. Specific items covered in this work plan included the following:

- The use of Ground Penetrating Radar (GPR) and surveying to identify the retrieval site and staking to delineate site boundaries.

- Pre-startup checks for weather requirements in order to ensure that wind, temperature, and moisture were within acceptable limits.

- Trench surveys to ensure that all flagging and staking were done properly and were complete.

- Sampling of the riser pipe gases for combustible and organic gases.

- Checks to ensure that all personnel had completed the proper training.

Pre-job planning meetings were conducted to confirm that all necessary personnel, equipment, and paperwork were available, and an operating log was maintained throughout the duration of the project.

\subsubsection{LANL Approach}

Prior to starting retrieval, LANL used GPR to locate storage pad containers. However, results were poor, and a probe was subsequently used to determine the top of the drums. In addition, extensive soil sampling was conducted to determine the fate of the overburden soil. Results of the soil-sampling program demonstrated the soil was contamination-free and could be used as fill in LLW disposal trenches or disposed of.

Initially, the LANL retrieval project erected a temporary building (dome) over the Pad \#1 retrieval site. The retrieval enclosure building $\left(\mathrm{RUBB}^{\circledR}\right)$ was designed to be HEPA filtered. About two feet of the soil overburden was removed from Pad \#1 and the RUBB $^{\circledast}$ dome was set in place over the trench. Because not all of the soil was removed before the $\mathrm{RUBB}^{\circledast}$ covering was placed over the pad, the following problems occurred:

1. Equipment and employee access was restricted. 
2. Employee safety became an issue.

3. Emissions from the soil removal vehicle(s) caused a continual monitoring issue and limited work scope and worker time allowed in the dome.

Later evaluation determined that the covering structure was not needed, and retrieval from Pads \#2 and \#4 is being conducted in open air (Demiter, 1998).

\subsubsection{SRS Approach}

Like LANL, the SRS retrieval project began by erecting a temporary RUBB ${ }^{\circledast}$ building (dome) over the retrieval site. Later evaluation of conditions during retrieval led to the decision to eliminate the use of the $\mathrm{RUBB}^{\circledast}$ structure and complete the retrieval as an open-air project (Demiter, 1997).

\subsection{SET-UP AND INSPECTION OF NDA EQUIPMENT}

The NDA equipment will be located in or near the retrieval trench. Actual placement of the NDA equipment will depend upon the space required for retrieval activities and the space available in the trench. In the event that space constraints in the trench require the NDA equipment to be placed outside of the trench, its location will be placed as close to the retrieval trench as safely possible. This placement strategy minimizes the required movement distances for the retrieved drums. It will also allow for efficient repositioning within the burial ground of those drums that assay as LLW.

A qualified contractor will provide the NDA equipment and services and will be responsible for setting up, maintaining, and servicing the unit. The equipment will be mobile. The unit will be self-contained and a generator will provide power for operations. The electrical generator will be placed outside of the burial ground boundaries. No on-site utilities will be needed for operation of the unit.

\subsubsection{Current SWBG ISB Approach}

The staging and NDA of drums is authorized under the current SWBG safety authorization basis. 


\subsubsection{Pilot Retrieval SAR Approach}

The Pilot Retrieval activities included NDA of the retrieved drums; however, NDA was performed off-site at the Transuranic Storage and Assay Facility (TRUSAF). This facility was previously set up to provide NDA capabilities. The TRUSAF assay capability is no longer available.

\subsubsection{LANL Approach}

Non-destructive assay was not included within the scope of LANL TRU retrieval activities.

\subsubsection{SRS Approach}

Non-destructive assay was not included within the scope of SRS TRU retrieval activities. 


\subsection{EXCAVATION ACTIVITIES}

Once pre-operational activities are concluded, excavation of the retrieval trench will begin. This chapter describes the removal of the earthen overburden from the waste containers, the monitoring and inspection that will accompany excavation activities, the handling and storage of any soils that are found to be contaminated, the placement and handling of spoils piles, and the removal and disposition of the tarp and plywood overlaying the drum modules.

\subsection{UNCOVERING OF DRUMS}

The excavation will proceed in a step-wise manner. First, the soil on the trench approach ramps will be removed by front-end loader vehicle. Then the soil overburden will be removed from the drums beginning at the west-end of the stack. This will be best done using a front-end loader or a SKY TRAK ${ }^{\text {\2 }}$-type vehicle with the front-end loader attachment. Hand tools or vacuum systems may also be used for soil removal operations. A mechanical means of removing the major portions of the soil is recommended. Excavation can be performed from the asphalt pad with a vehicle having a reach of over 25 feet.

Overburden soil will generally be removed one module at a time. In addition, the reach on the excavation equipment may limit the amount of soil that can be removed at one time. Uncovering of at least one-half of a module (six rows or approximately 15 feet) at the start of a module is desired. As the drums may be retrieved in a stair-step layer pattern, the number of rows of the top tier that are uncovered will vary as rows and tiers are removed and further access to the overburden is obtained by the excavation equipment. The stair-step retrieval pattern will also vary as boxes are retrieved.

Soil adjacent to the trench (north and south) will be removed by backhoe or a SKY TRAK $^{\text {}}$ type vehicle. Hand tools or a vacuum system may also be used for soil removal. Soil removal will be conducted so that the correct trench wall slope (1 vertical to 1.5 horizontal) is maintained.

\subsubsection{Current SWBG ISB Approach}

The uncovering or retrieval of earth-covered containers is not within the scope of the SWBG ISB. The SWBG ISB currently states that "Retrieval of buried TRU waste beyond the vented drums as analyzed in [WHC-SD-WM-SAR-058] will require approval of additional safety analyses that revise the Solid Waste Burial Ground authorization basis." The referenced document is the Final Safety Analysis for Contact-Handled Transuranic Waste Drum In Situ Inspection and Vented Drum Retrieval" (Joyce and

\footnotetext{
${ }^{2}$ SKY TRAK is a registered trademark of Sky Trak International, Inc., a subsidiary of OmniQuip International, Inc.
} 
Harker, 1993). Thus, the existing safety basis will allow exhumation of about 100 buried drums, but the remainder can not be excavated without a specific modification to the ISB. These modifications are not necessary for the retrieval of uncovered drums, but are required before excavation of buried drums can occur.

\subsubsection{Pilot Retrieval SAR Approach}

The pilot retrieval operation was limited in nature, as it was to be a one time operation. Work was to be conducted only during daytime and during periods of good weather with temperature and wind limitations. No activity could be conducted in adjacent trenches during retrieval operations.

Excavation took place at the center part of the modules and soil was removed from the sides (north or south) of the trenches only. Heavy equipment was operated no closer than five feet from the edge of the excavated trench.

After all pre-operational items had been completed, a pilot hole was dug (by hand) to locate trench module top and corner. Trench flagging and staking was required. Heavy equipment (front-end loader and crane bucket) was used to start the excavation, but the heavy equipment was not used to excavate any closer than 1 foot from the nearest drum module boundary. Hand tools were used to clear all soil within the 1-foot limit. Results of all soil sampling at the two retrieved sites indicated that the soil was contaminationfree (both radioactive and hazardous).

Heavy equipment could not operate within 5 feet from the edge of the excavated trench. The entire accident analysis only allowed for excavation from the sides of the trenches (North or South).

\subsubsection{LANL Approach}

Once the RUBB ${ }^{\circledast 3}$ dome was set, the remaining two feet of soil overburden was removed by the SKY TRAK ${ }^{\circledR}$, using the bucket attachment. This was somewhat cumbersome, due to space and mobility limitations imposed by the proximity of the RUBB ${ }^{\circledast}$ structure. Once the soil overburden was removed, only the tarp covering and the plywood were left covering the drums. Prior to removing drums, which are stacked five-high at LANL, any remaining soil on the top tier of plywood was removed from the area of retrieval by workers in a man-lift attached to the SKY TRAK®.

\footnotetext{
${ }^{3}$ RUBB is a trademark of RUBB Building Systems.
} 


\subsubsection{SRS Approach}

After reviewing lessons learned at other DOE sites, SRS concluded that the retrieval of TRU drums was an extension of the present work at the Solid Waste Management Facility (SWMF). Removal of the soil overburden was the only activity not being conducted routinely at the SWMF, and further analysis demonstrated that no additional hazards to ongoing operations were posed by the soil removal activity.

Retrieval activities began with the removal of the top two feet of overburden soil around and atop the pad. The RUBB ${ }^{\circledR}$ structure was then assembled over the pad. The SRS drums were only stacked two-high, unlike Hanford or LANL.

The original scope called for the removal of the final two-foot layer of soil to be done by vacuum truck. To accommodate the use of the vacuum truck, the soil was to be loosened using hand tools. Further analysis showed that the amount of dirt to be removed at any given time was expected to be minimal (approximately three cubic feet) and, if done entirely by hand, would not impact the project's critical path. Therefore, the vacuum truck was not used for soil removal, and the last layer of soil was removed by hand. The SRS experience showed that, after the pad end was opened, almost all soil could be removed with equipment or when the plywood was removed.

\subsection{MONITORING AND INSPECTION DURING EXCAVATION ACTIVITIES}

Retrieval operations that involve excavation will require the development of a new Radiation Work Permit (RWP). RWP's to address contingencies (such as a breached drum) will be developed on an as needed basis. Surveys to identify areas of radioactive contamination will be conducted prior to excavation. Operations will be conducted in accordance with ALARA and the requirements for radiation work planning.

Air monitoring for radionuclides should be completed as part of standard retrieval operations. The use of continuous air monitors should be considered to allow for the monitoring of any increase in radionuclide emissions beyond the background established for the burial grounds. Dust suppression will be employed as needed.

\subsubsection{Current SWBG ISB Approach}

The current SWBG ISB does not provide for the uncovering or retrieval of buried waste drums. Therefore monitoring during excavation activities has not been addressed. 


\subsubsection{Pilot Retrieval SAR Approach}

A Soil Sampling Plan was developed to monitor for soil contamination (radiological, hazardous, and non-hazardous) at the first five drum retrieval sites. Chain of custody, qualified laboratory selection, assuring non-radioactive samples for off-site shipment, and meeting Quality Assurance requirements became issues for implementing the plan. The plan also developed an analytical procedure for random sampling.

The trench riser gas sampling conducted prior to TRU drum retrieval was a simple, inexpensive method of providing trench data. The riser sampling helped bound pre-start conditions and provided hazardous/explosive gas and radionuclide information.

An industrial hygienist was part of the Pilot TRU Retrieval Staff. The hygienist had the responsibility to conduct air sampling, perform air monitoring activities, and maintain logs and reports to ensure employee exposures were kept below occupational limits.

Supplemental continuous air monitoring units were placed during the project to measure any increase in radionuclide emissions beyond the background established for the burial grounds. The two units were placed east and northeast of the retrieval sites to assure downwind coverage. Although the new units did not detect radionuclide increases above background levels, they provided an increased measure of protection and advanced warning (Schmidt et al., 1995).

\subsubsection{LANL Approach}

LANL has adopted the radiological protection ALARA philosophy. LANL Administrative Requirement 6-2, specifies how the Environment, Safety and Health division monitors LANL workplaces to ensure that exposures are maintained ALARA and kept below the Occupational exposure limits.

Each major task has been analyzed for specific hazards using their Task Hazard Analysis form. Air samples are collected to establish baseline data from which project operations, personnel protective equipment, and monitoring requirements are determined.

Numerous control methods (e.g., engineering, administrative and work practices) are utilized to minimize radiological hazards.

Radiological Control Technicians (RCTs) are assigned full time and are present during operations involving radiation or where surface or air contamination may occur. The $\mathrm{RC} T$ s perform thorough surveys of the work area during work activities.

Air monitoring is performed in accordance to site air monitoring standards. Continuous air monitors are used to monitor airborne alpha radioactivity and may be used to 
determine if airborne beta radioactivity is present or at levels that present an inhalation hazard.

\subsubsection{SRS Approach}

No monitoring or pre-sampling was done prior to excavation at SRS. Soil removal posed no hazard increase to workers during the handling and movement of TRU drums. SRS required coverage by Radiological Control Operations while operations were in progress.

The retrieval area at SRS was roped off as a Radiation Area. The Radiological Work Permit (RWP) specified that the retrieval pad sites were not airborne radioactive areas. As such, no protective clothing requirements were given. The retrieval crew was allowed to wear work coveralls or "blues" while conducting retrieval operations. The RWP discussed employee responses if a damaged or leaking drum was found or contamination was detected.

SRS did have an agreement with the state of South Carolina to conduct soil sampling as part of the burial ground closure process.

\subsection{HANDLING AND STORAGE OF CONTAMINATED SOILS}

Phase I retrieval activities will not remediate the burial grounds. If contaminated soil is encountered during retrieval, the PPE will be adjusted as directed by the Radiological Work Permit. Small amounts of incidental contaminated soil may be placed in drums or boxes, and the packages will be staged as appropriate while the paperwork required for newly-generated waste is developed. As necessary, larger areas of contamination may be fixed and the area posted as a soil contamination area. Bulk transfer of contaminated soils for disposal in another trench may also occur.

\subsubsection{Current SWBG ISB Approach}

Since the current SWBG ISB does not provide for the uncovering or retrieval of buried waste drums the ISB does not address handling of contaminated soil during excavation.

\subsubsection{Pilot Retrieval SAR Approach}

For any soil found during excavation or retrieval that had contamination in excess of the allowable limits, the HWOP designates the required course to follow including requirements for evaluation and recovery. 


\subsubsection{LANL Approach}

A minimal amount of contaminated soil (attributed to breached or leaking FRP boxes) was found. LANL developed a small HEPA filter system that could be fitted over the local area of the spill to help with contamination control while the contaminated soil was removed. Contaminated soil is being packaged in 55-gallon drums. Some contamination has penetrated the asphalt pad; so SRS is fixing the contamination by painting the pad as they retrieve. To date, approximately 12 drums of contaminated soil have been generated after retrieval of 10,000 drums and 200 boxes (Demiter, 1998).

\subsubsection{SRS Approach}

SRS handled contaminated soils very much like LANL. Soils were packaged in 55gallon drums for disposal. Throughout the first four TRU pads, only one breached drum was found and less than one drum of contaminated soil was generated. During the retrieval of the last TRU pad, 11 drums of contaminated soil were generated (Demiter, 1997).

\subsection{PLACEMENT AND HANDLING OF SPOIL PILES}

As soil is removed from the trench site it should be piled up in the area between the trenches or moved and stored at location near the work area. This soil will be used at a later date to backfill trenches or as needed in the SWBG.

\subsubsection{Current SWBG ISB Approach}

Since the current SWBG ISB does not provide for the uncovering or retrieval of buried waste drums it does not address the subject of spoil piles (excavated material). However, the ISB does specify limits on the handling of bulk waste that may be applicable to this excavated material.

\subsubsection{Pilot Retrieval SAR Approach}

The soil was piled nearby and returned to the excavation area following completion of retrieval activities. Since this was a pilot project, only a few specified drums were removed and replaced with dummy drums. The trench locations excavated were recovered using the material removed during the excavation activities, and the site was returned to the as-found condition. 


\subsubsection{LANL Approach}

Extensive soil sampling was conducted to determine the fate of the overburden material. The results of the soil-sampling program demonstrated that the soil was contamination free and was to be used as fill in LLW disposal trenches.

\subsubsection{SRS Approach}

The excavated soil, similar to LANL, was used as backfill to LLW areas and as needed throughout the burial ground.

\subsection{REMOVAL AND DISPOSITION OF TARP AND PLYWOOD OVERLAYS}

All plywood sheets should be inspected for deterioration and contamination before anyone is allowed to work from them. The man-lift attachment will allow for removal of plywood from the top drum tiers or fall protection can be supplied. Only the sheets of $3 / 4$ inch plywood from the top tier, but none of the $1 / 4$ inch sheets used between the tiers, should be used for work platforms. As tiers are removed the $3 / 4$ inch plywood can be moved and placed over or replace the $1 / 4$ inch plywood separating the tiers. Direct walking on drums should not be allowed. Plywood should be removed only when inspection or retrieval is required. Plywood should remain over drums during periods of poor weather.

Since the orientation of the 4-ft $x$ 8- $\mathrm{ft}$ sheets of plywood is unknown, it may be necessary to cut the sheets to provide access to the drums under them. Cutting can be done using an battery operated saw.

Once the plywood has been removed from an area the underlining tarp should be rolled back to expose the rows of drums beneath. Any plywood that is removed should be stacked out of the way for future use. Plywood that has deteriorated to the point that it is no longer adequate should be disposed of appropriately. It is recommended that plywood sheets be reused as separators for the relocated LLW drums.

As the tarp is removed it should be assessed as to its condition. If the tarp is in good shape it should be folded up and stored for future use with the LLW drums. Tarps in bad shape should be disposed of in accordance with applicable waste designation and packaging requirements. 


\subsubsection{Current SWBG ISB Approach}

The current SWBG ISB does not provide for the uncovering or retrieval of buried waste drums. Therefore handling and disposition of plywood and tarps removed from the burial sites is not addressed.

\subsubsection{Pilot Retrieval SAR Approach}

The Pilot Retrieval Project was limited in scope and was not intended to remove more then a few drums. After the targeted drums were removed they were replaced with dummy drums and the modules were reconstructed and returned to its original configuration by covering the module with a tarp and back filling with soil. Since only limited areas were excavated only portions of the tarp and plywood were exposed and removed for retrieval. The plywood was removed and set aside and the tarp opened as required to retrieve identified drums. The plywood and tarp were then replaced and the site returned to the as-found condition.

\subsubsection{LANL Approach}

Plywood sheeting was released as non-contaminated and reused.

\subsubsection{SRS Approach}

Removed plywood sheeting was released and disposed of as LLW. 


\subsection{INSPECTION AND RETRIEVAL ACTIVITIES}

This chapter addresses the initial container inspection, container dose and shielding requirements for handling, retrieval of the containers to the inspection area, drum inspection, and the retrieval of drums with questionable integrity. The inspection and retrieval activities described in this chapter apply only to stacked containers that are stored on asphalt pads in $218 \mathrm{~W}-4 \mathrm{~B}$ and $218 \mathrm{~W}-4 \mathrm{C}$ burial grounds. Chapter 10 contains a discussion of the deviations from the standard stacked container inspection and retrieval activities that may be required for specific groups of drums (i.e., for drums placed in the TV-7 trench configuration).

\subsection{INITIAL CONTAINER INSPECTION}

Initial container inspection will commence when the following conditions are met.

1. The earth overburden, the plywood overlaying the tarp, and the tarp module cover are removed sufficiently to expose the first several rows of the trench (west-end retrieval face).

2. The soil adjacent to the trench (north and south sides) has the angle of repose set at $1.5 \mathrm{H}$ to $1.0 \mathrm{~V}$.

A Container Retrieval Data Form, such as the form shown in Figure 6-1, will be prepared for the containers expected to be retrieved each day. Initially, these sheets will include the historical information listed below, as available.

- container number

- size

- weight

- surface dose

- container position in the module

- TRU content (grams)

During the initial inspection at the module face, the information listed below will be confirmed.

- surface dose

- container number

- module position

- vent clip installation

- container size

- weight (if NDA is performed) 


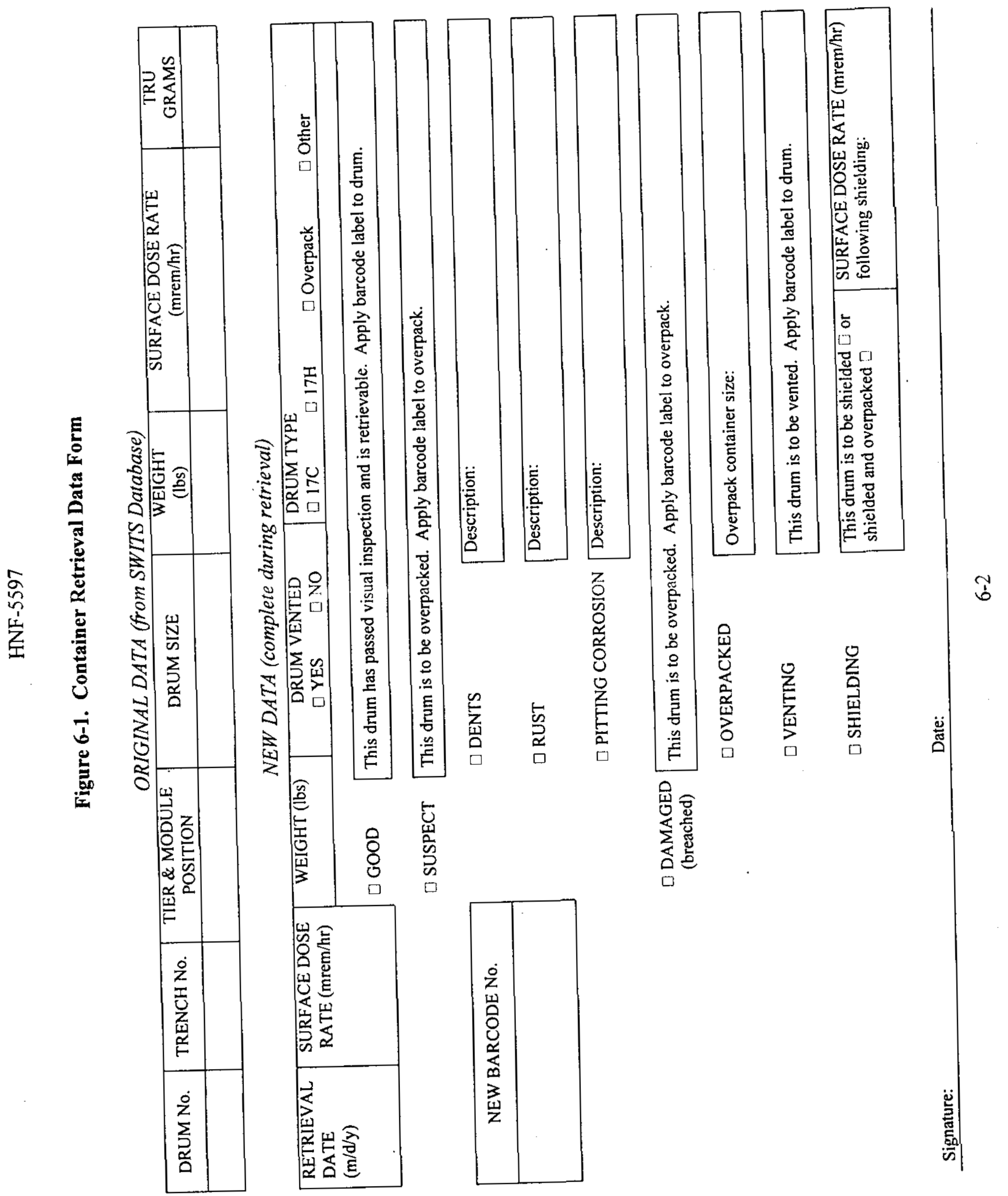


In addition, the following new data will be collected for each drum.

- retrieval date

- container condition (dents, rust, corrosion, etc.)

- contamination

- container breach (including wrap and overpack requirements)

- new bar code number installation

- drum type (e.g., 17C, 17H, overpack)

The completed data form will become part of the permanent container traveler package. Chapter 9 discusses the documentation of the data collected during both the records review and the retrieval process in greater detail.

The container inspection will require equipment that has the capability to lift inspectors in a safety cage device up to 15 feet in height to inspect container conditions, conduct surveys, and lift and transport containers (from a stacked position 12 feet high) to a final inspection area. Containers to be inspected include 55-gallon drums, 30-gallon drums, 85-gallon drums, 110-gallon drums (two 55-gallon drums welded end-to-end), metal boxes, FRP boxes, concrete boxes, and tanks.

The inspection of the drums need only demonstrate that the drums have sufficient integrity to meet their principal feature of providing containment. Initial container inspection to determine retrievability will be divided into two types: one for 55-gallon, 85-gallon and 30-gallon drums (the specific focus of TRU retrieval process description) and the second for all other container types listed above. Discussion of inspection and retrieval of other than drums will be covered in Chapter 10.

The initial drum inspection $(55,30$, and 85 -gallon) will require inspectors to be raised to the top of the drums in the stack (if the module has a straight vertical retrieval face). The top of the five-high stacked drum module one is 15 feet above the asphalt pad. If the module is already stair-stepped, the row to be inspected will be selected to maintain the module stair-step configuration. Exposed drums in the selected row of the module will be surveyed and smeared for any contamination. Loose soil atop the drum may need to be removed to complete the smears. The Container Retrieval Data Form will be relied on for existing drum data and cautions for conditions such as high dose. (Handling containers with high dose will be covered in Section 6.2.)

Following initial surveys to confirm the drum is contact-handled and contamination free, the exposed drum face and top will be inspected to confirm the unique drum number, specific location within the module, the presence or absence of a vent clip, and container soundness. Dents, rust or pitting corrosion or holes in the drum will be noted on the Container Retrieval Data Form, but final determination of these conditions will be made at the drum inspection area. Several retrieval face drums can be inspected, one at a time, up through this step. (It is recommended that all twelve drums in the selected row of the module be inspected before going to the next step.) 
Once the retrieval faces of the selected drums are inspected, the drum backs must be inspected. It is suggested that a mirror on a pole be used for the backside viewing operation. Complete drum bottom inspection will be conducted at the drum inspection area, but the bottom can also be checked as the drum is brought down from the stack.

It is anticipated that drum information will be recorded on several Container Retrieval Data Sheets that will be with the drum inspectors in the man-lift of the drum retrieval equipment. The operator will simply move the inspectors north or south, along the drum face in the man-lift, to the next drum to be inspected. In this manner, inspectors can inspect the entire row before being set down by the operator on the asphalt pad. Alternating retrieval and inspection of the selected drum rows will continue in this manner throughout the module.

Drums that will require special handling attention will be those that:

- Do not have a vent clip.

- Have a high dose (above project limit) and require shielding and overpacking.

- Fail the retrievability inspection and must be wrapped and overpacked.

- Are contaminated.

- Exceed the 200 FGE limit

- Are remote-handled; greater than $100 \mathrm{mR}$ at $30 \mathrm{~cm}$ and require shielding and overpacking

- Do not have a U. S. Department of Transportation (DOT) 17C or 17H stamp on the bottom.

Discussion of the above conditions can be found in Sections 6.2 and 6.5.

\subsubsection{Current SWBG ISB Approach}

Retrieval of earth-covered TRU containers is outside the scope of the current SWBG ISB. Therefore, provisions for inspection of retrieved TRU containers is also outside the scope.

\subsubsection{Pilot Retrieval SAR Approach}

WHC-SD-WM-SAR-058 set the limitation of in situ inspection and retrieval to a maximum of $138 \mathrm{CH}$-TRU waste drums from four sites in the $218 \mathrm{~W}-4 \mathrm{C}$ burial ground 
and one site in the $218 \mathrm{~W}-4 \mathrm{~B}$ burial ground. All drum inspection was done adjacent to the storage module prior to removal of the drum from the module area.

The drum inspection was conducted to collect corrosion data for the stored drums. However, the Pilot Retrieval SAR (Joyce and Harker, 1993) only authorized inspection/ retrieval of vented drums on asphalt pads, thereby limiting the inspection/retrieval to five sites and one drum configuration type. The corrosion data obtained by the Pilot Retrieval Project were to be used to extrapolate drum life for the drum storage conditions in light of the requirement that waste containers be readily retrievable, in contamination-free packages, for up to 20 years (AEC, 1970).

In order to be retrieved, drums had to pass the following inspection criteria:

- In situ Non-Destructive Examination (NDE) to determine that minimum wall thickness of the drum is 0.042 inches or greater (i.e., compliant with a DOT-17H drum)

- Be a 55-gallon drum

- Contain a Hanford vent clip

- Weigh 800 pounds or less

- Not be breached or deteriorated to the extent that safe transport and storage is questionable

- Not be bulged

- Lid is visibly secure

- Labeling/identification is sufficient to confirm identify

- Comply with smearable contamination limits

- Not exceed $200 \mathrm{FGE}$ or contain $>12 \% \mathrm{Pu}-240$ based on existing records

- Have a contact dose rate $<200 \mathrm{mrem} / \mathrm{hr}$

Inspection was to be conducted on a single-drum stand, however, the final inspection stand was a four-drum stand. Drawings for both stands are included in the SAR (Joyce and Harker, 1993). 


\subsubsection{LANL Approach}

LANL drums were stacked five-high with large FRP boxes placed down each side to line and contain the drums within the trench. The approach for inspection, and subsequent retrieval, was to start at one end of the trench and move progressively down the trench. LANL drums were placed at ground level and covered with soil differing from Hanford's placement below grade. Once the earth was removed, no soil angle of repose issue would affect inspections and much more room adjacent to the trench was available for laydown, movement, inspection, etc.

LANL drums were much like Hanford's in that they could contain 200 grams $\mathrm{Pu}$, or more and were contained in a similar storage arrangement in similar type soil. Unlike Hanford drums, all LANL drums stored in the trenches were only contact-handled and were unvented so an inspection for vents was not required.

LANL initial inspection, after uncovering and exposing the drum face, was to inspect the top row of drums from a manlift mounted on front of a Skytrak vehicle. The Skytrak manlift would hold two workers and equipment with a total capacity load of 800 pounds. The workers would inspect the drums generally to gain dose, contamination, and general drum condition data. The drums could be stacked 15 abreast, although the drums shown in (Demiter, 1998) were only 7 abreast at the back of the trench.

Drums were not inspected to any criteria, [e.g., Department of Transportation (DOT) drum wall thickness shipping requirements for new drums]. LANL used only a visual inspection and operations experience is assessing retrieved drum condition.

The job lead conducted a visual inspection of the drums, from the manlift, for visible signs of leaks, severe corrosion, or physical damage. If there was a doubt about the drum condition, the lead conferred with the industrial safety representative and they jointly assessed the drum condition. LANL developed a plastic plate that would slip under poor condition drums and be held to the drum bottom by three straps that clipped over the drum lid ring. Poor condition drums could be inspected completely, with the bottom being visible through the plastic plate.

A drum data form was filled out prior to inspecting the drums. The data from had original data from the LANL.TRU Waste Database on the drums. The data on the form was confirmed at the retrieval face inspection. The form had the following original data:

- Drum number

- Label number

- Drum size

- Contents description

- Weight

- Surface dose rate

- Possible $\mathrm{H}_{2}>$ Lower Flammability Level 
The new data requested on the form from the drum face inspection was:

- Retrieval date

- Surface dose rate

- Drum condition

- Visual inspection comments

All other drum condition data were gathered at the inspection area.

\subsubsection{SRS Approach}

SRS drums were stored only two high and covered with a clay soil that packed tightly around the drums and held the drums tightly in the storage arrangement. The SRS TRU drum pad storage was only to contain drums with $<0.5$ curie $(\sim 8.2$ grams Pu239 equivalents) of TRU radionuclides, although some drums were found that contained 20 to 30 grams $\mathrm{Pu}$. The SRS standard was to have all drums containing $>0.5$ curie TRU radionuclides stored in below ground culverts. SRS did make an exerted effort over the years to maintain the $<0.5 \mathrm{Ci}$ limit to eliminate the potential problems that could be caused if highly loaded Pu 238 drums were intermixed within the stored TRU drums. SRS did however have to deal with boxes and casks stacked within the drums that had contact dose readings up to $600 \mathrm{mR}$.

Data for the SRS drums was contained on the Computerized Burial Records Accounting (COBRA) database. The database provided limited information on the stored containers (isotopic distribution, generator, date shipped, date received, date placed, dose and specific drum number). Also given in the database was the location of the drum given only by grid coordinates of the area. Therefore, specific location of the drum within the grid was not exactly known, only that it was somewhere in the given grid location. (Typically the grid was about a 25 -foot square.)

The information from the COBRA system was available to the inspection and retrieval crew but was only used when a drum or container was found to be outside the general retrieval criteria and set aside for disposition.

After mechanical removal of soil covering the drums, and in some cases a cargo netting, the working supervisor (operator) removed the plywood covering and any remaining soil with a shovel so the top of the drum could be inspected with a mirror on a pole. (Plywood was placed atop the drum stack and between the two layers.) After his visual inspection of the drum, a forklift operator removed the drum from the stack and the lead operator inspected behind the drum and the drum bottom with the mirror on a pole for any defects or severe corrosion. The drum was then moved a short distance and the Health Physics Technician (HPT) surveyed the drum while being held by the forklift operator. The inspection was completed at the final laydown/inspection area. 
The inspection paper work was generated at the final inspection area. Drums that had any specific problems, i.e. surface contamination, $>0.5$ curie TRU radionuclides, high dose, etc. were segregated on plastic pallets awaiting disposition.

All drum inspection for the assessment of retrievability was visual. Only one drum had a corrosion pin hole and only 12 drums were overpacked in 8,803 drums inspected and retrieved at SRS. The inspected and retrieved drums from SRS were placed in storage from 1974 through 1985.

\subsection{HANDLING CONTAINER DOSE AND SHIELDING REQUIREMENTS}

TRU inspection and retrieval will encounter high dose containers that must be placed in a safe and segregated condition while maintaining safety for employees while utilizing ALARA principles.

Dose and shielding problems encountered will be resolved differently for drums versus large containers. High dose drums may effectively be covered with a shielding mat while large boxes do not lend themselves to this principle well. Principles of time and distance will have to be used during the retrieval and movement of large boxes.

If an initial inspection reveals that a drum dose is above retrieval limits or that the drum is RH-TRU, at least two methods of retrieval and handling can be used: a shielded shroud or ALARA time and distance principles. Note that the uncovering and retrieval of wastes $>100 \mathrm{mrem} / \mathrm{hr}$ at $30 \mathrm{~cm}$ is not authorized under the current SWBG safety basis. This is the limit for posting a High Radiation area.

A shielding fabric shroud may be placed over the drum after it is removed from the module. The shroud will shield the top and sides of the drum and be lowered over the drum utilizing straps on top of the shroud. Once the shroud is positioned over the drum, the drum can be removed to a controlled area. The drum may then be placed in a shielded overpack drum or other container. The drum may simply be placed on a small cargo net that has several lifting rings in the fabric at the perimeter of the netting. Once the drum is placed in the center of the cargo netting, the rings can be brought over the shielding shroud and drum and clipped to the hook of the drum lifting equipment. The cargo netting will need to be capable of lifting approximately 2,000 pounds. The drum can then be lifted and placed in the shielded overpack. The cargo netting rings can be set over the outside edge of the container and the drum shielding shroud lifted off the drum for reuse. The cargo netting rings can then be laid on top the drum and any shielding and the lid of the container installed and closed. In the future, when the drum needs to be removed from its overpack, the rings on the cargo netting will again be used to lift the drum from the overpack.

The second method of handling high dose drums is to simply employ the ALARA principles of time and distance. These actions alone may be sufficient to provide the needed employee protection for the occasional high-dose drum. 


\subsubsection{Current SWBG ISB Approach}

The current ISB indicates the containers must be covered with soil three to four feet thick anytime the container dose rate exceeds $100 \mathrm{mrem} / \mathrm{hr}$ at $30 \mathrm{~cm}$. This is the limit for posting a High Radiation area.

\subsubsection{Pilot Retrieval SAR Approach}

Uncovering and retrieval of RH-TRU containers (contact dose rate $>200 \mathrm{mrem} / \mathrm{hr}$ ) was not authorized under the Pilot Retrieval SAR (Joyce and Harker, 1993). A lead (Pb) blanket was fabricated to place over high-dose drums that were retrieved; but the $\mathrm{Pb}$ blanket was never used.

\subsubsection{LANL Approach}

Only drums reading $<100 \mathrm{mrem} /$ contact were to be stored on the LANL TRU retrieval pads. LANL has retrieved a few drums that read $>100 \mathrm{mrem} /$ contact but no drum that has read $>200 \mathrm{mrem} /$ contact. The large FRP boxes have been found in relatively good condition and those on Pad \#4 were in better condition than those on Pad \#1. No high dose conditions have been found among the large boxes.

LANL did employ the use of a lead (Pb) blanket design (specific LANL design) for use during retrieval of high dose drums. The shielding slipped over the top of the drum and hung on the lip. In this manner, high-dose drums could be removed from the stack and placed in the RH-TRU below ground shafts (culverts).

\subsubsection{SRS Approach}

SRS did encounter high-dose boxes and drums in culverts during TRU pad retrieval. Two drums were contained in the seven-foot metal culverts. The metal culverts may have had grout placed around and atop the drums. Cranes or large forklifts were used to move the high-dose culverts or boxes. No shielding was placed over the containers or between the containers and the driver. The containers were moved to the fenced highradiation area. The ALARA principles of time and distance were employed to maintain employee dose within site guidelines.

\subsection{RETRIEVAL OF CONTAINERS TO INSPECTION/LAY-DOWN AREA}

Actual removal of the drums from the stacked module will occur one at a time utilizing the drum-retrieval equipment. The retrieval equipment must be able to lift a 2,000 pound drum from a stacked position, approximately 15 feet up. If a shielding shroud is placed over a high-dose drum, the lifting equipment must be able to lift the drums with the 
shroud in place. The retrieval equipment must be able to handle/lift 30,55 and 85 -gallon drums without complex adjustments to the lifting feature of the equipment. The shroud design may be so fabricated as to not impact the lifting equipment/drum interface.

Retrieval should begin at the exposed, western end, of the trenches and proceed down the trench. Retrieval that will involve approaches from the north or south should only be used to remove large boxes or containers by equipment set-up between the trench at ground level. Such removal, from the north or south of the trench, would use cranes or heavy equipment capable of reaching from the area between the trenches to the container requiring removal. The area between the trenches may be limited, due to spoil pile placement and care must be taken to maintain the trench angle of repose for retrieval.

The inspection area should be kept as close as reasonable to the retrieval face to minimize drum/container movement, pending completion of final inspection.

The initial module to be retrieved may have a straight face, consisting of drums stacked four or five tiers high, or it may be stepped, with drums stacked in a stair-step manner on different tiers. Regardless, the retrieval should proceed from the west end of the trench and involve removal of the drums to maintain the stair-step arrangement of the module whenever possible. Removal of several rows of drums, most probably from the uppermost tier first, may be required so plywood sheeting between the tiers may be removed. This same process (removal of several drum rows per tier) may then be repeated throughout the other tiers to maintain the stair-step retrieval of drums from the module. (Review of module photographs reveals that the plywood sheeting between drum tiers can have the 8-foot dimension oriented east-west or north-south. Photographs also show that the orientation of the plywood is consistent throughout the tier.)

Removal of the intact 4-foot by 8-foot sheets of plywood is the preferred option for drum retrieval. It may, however, become necessary to cut some plywood tier separators with a saw to maintain the stair-step retrieval approach. Fall protection may be required for workers performing these activities on the upper tiers of the module. It is anticipated that the removed plywood sheeting and tarp coverings will be reused as tier separators between the stacked LLW modules and module covers, thereby reducing waste generation.

Retrieval will be required from modules where the drums are stacked right next to each other. The retrieval equipment must be able to achieve a positive pick on the drum from this configuration. The drum retrieval equipment should not rely on the drum lid ring as a lifting point since the drum lid ring tightness can not be attested to until the drum is placed in the inspection area and the bolt is torqued to meet specifications. It is most likely that retrieval will be conducted from the open end of the row but it is possible an initial drum retrieval may come from the center of the module if boxes bound both ends of the row. 
Retrieval of large containers will be conducted with heavy equipment, cranes, large forklifts, etc. that may be located within the trench or between the trenches. This aspect of retrieval will be covered in Chapter 10 .

\subsubsection{Current SWBG ISB Approach}

Retrieval of earthen covered containers is not authorized under the current SWBG ISB.

\subsubsection{Pilot Retrieval SAR Approach}

Pilot retrieval only authorized retrieval of vented 55-gallon drums and did not authorize retrieval of unvented drums or boxes. The drums had to comply with retrieval criteria (given in Section 6.1.2). The drums were retrieved using a large motor crane and a drum lifting device that clamped below the drum ring as the drum was lifted in a scissor-type grip. The drums were weighed with a dynometer that was connected above the drum lifting device.

The retrieval of drums did not occur from the stair-step face of the module. Retrieval occurred from the side of the module. The crane movement was not intricate enough while retrieving drums and several times a drum being retrieved hit adjacent drums or drums already retrieved and placed on the ground. Damage did not occur but drums were nearly knocked over.

The retrieval of drums to the inspection/staging area by the crane did not allow for any secondary movement of the drums for staging, rearranging or inspection. If drums had to be repositioned or rotated for final inspection, labeling, etc. they were moved by hand, either sliding or rotating them on the plywood sheeting. Since multiple movement of the drums will be required from retrieval, inspection, NDA, staging, shipping, it is recommended a crane not be used but rather equipment that can perform all the drum retrieval and movement functions.

\subsubsection{LANL Approach}

A vehicle called a SKY TRAK ${ }^{\circledR}$ accomplished the movement of drums and containers to the inspection/lay-down area. A 15-ton forklift for the large FRP boxes. The SKY TRAK $^{\circledast}$ vehicle can be outfitted with any of four adapters:

- A front-end loader to remove soil overburden

- A caged man-lift capable of lifting 800 pounds

- Forks for a forklift

- A drum-grabber to retrieve or move drums 
LANL drums were stacked five-high and bordered by drums. The SKY TRAK ${ }^{\circledast}$ could easily remove tight-stacked drums with the drum-grabber attachment. LANL retrieved drums in excess of 2,000 pounds with the SKY TRAK ${ }^{\circledast}$. The 1.5 yard front-end loader bucket was used to remove the soil overburden from the trench before and during retrieval. The caged man-lift was used to carry the two inspectors to the stacked drums for initial inspections and surveys. The SKY TRAK ${ }^{\circledast}$ also had large tractor tires for good traction and all-terrain use.

The retrieval of drums from the trench front-face followed this general sequence after uncovering was complete:

- The man-lift was installed and the lead and HPT was raised in the man-lift to survey, inspect and complete initial drum retrieval paper work

- After inspection of several drums, workers were lowered down and the man-lift was removed.

- The drum-grabber was installed and the SKY TRAK ${ }^{\circledast}$ operator retrieved the preinspected drums.

- The operator grasped the selected drum from the tier with the SKY TRAK ${ }^{\circledR}$ and back away from the stack with the drum. If required, drums were overpacked as the drum was brought down from the stack.

- The drum was lowered to the transport position.

- The retrieved drum was transported approximately 20 yards to the survey/inspection/weighing area.

- Following inspections and bar-coding, the drums were banded four to a pallet and loaded onto the transport truck using the fork attachments on the SKY TRAK ${ }^{\circledR}$.

As needed, earth was removed from the top of the trench using the SKY TRAK ${ }^{\circledR}$ and bucket attachment. Initially, LANL maintained a straight-wall and stair-step arrangement of the retrieval face. The retrieval face was primarily dictated by the arrangement of the large boxes at the perimeter of the trench. As retrieval began at the second TRU pad, the stair-step arrangement was maintained because the boxes were scattered throughout the trench and not around the perimeter.

Using this approach to TRU retrieval, the LANL average retrieval rate was 84 containers per week, with several weeks exceeding 100 . This rate included retrieval and inspection of over 9,400 drums and over 200 large FRP boxes, as well as labeling and loading drums for shipment to the drum washing and venting facility. 


\subsubsection{SRS Approach}

Both SRS and LANL bought large equipment believed needed for retrieval. At both sites, reassessments were done relative to the equipment needed to conduct TRU retrieval. Both sites eliminated several pieces of large equipment originally thought as mandatory for retrieval. SRS actually found the extra large equipment would pose a safety hazard. LANL also found this to be true specifically from hydrocarbon emissions that limited worker time at retrieval and equipment operating time. Since some equipment had been ordered and couldn't be returned without a charge, SRS paid the cancellation or restocking fees of up to $25 \%$ to return the equipment. LANL was able to cancel all their unnecessary equipment orders with no penalty.

SRS, like LANL, required only one piece of equipment for TRU drum retrieval. The required equipment was a forklift with a drum-grabber attachment on the front. SRS drums were only stacked two-high so the high-lift feature of the forklift (up to 204 inches) was not required.

After earth was removed by heavy equipment (leased from another organization) from the drums, the soil remaining atop the drums and at the sides was removed by the lead operator. The forklift operator would then lift the selected drum slightly as the lead operator would inspect behind and beneath the drum for signs of corrosion or defects with a mirror on a pole. The drum was then removed from the stack for the operator to complete visual inspection of the drum. The drum was then removed from the retrieval face area and brought to a central work area in front of the pad where the HPT would complete the drum survey. Following complete survey, the drum would be moved to the set-up and labeling area. This was the final lay-down area.

The SRS drum retrieval rate for the 8,800 drums retrieved was approximately 40 drums per day. The SRS TRU retrieval burial grounds operations works a 10-hour day and has each Friday off

\subsection{DRUM INSPECTION}

All retrieved drums will be inspected. The drum inspection will consist of a visual examination to assure that there is no significant corrosion, holes or dents are not present, and waste confinement is provided. The majority of drums should also bear a DOT 17C or $17 \mathrm{H}$ stamp on the bottom as that was a requirement for disposal. The DOT stamp, in conjunction with positive inspection results, insures the drum is fit for retrieval.

In the event the drum lacks the DOT stamp, the drum may still be deemed fit for retrieval by NDE of the drum to assure that the drum wall has a 0.030 -inch minimum thickness. The 0.030 -inch criterion is a SARP requirement for transportation of retrieved TRU drums to a TSD facility. If a few drums are discovered to lack the DOT stamp they may be overpacked. If many drums lack the DOT stamp, NDE may be performed to limit the number of drums that require an overpack. 
If drums assay as LLW and will remain disposed in the SWBG, no DOT stamp or NDE is required for reinterment.

The initial drum inspection will be at the retrieval face mainly to decide if the drum will provide containment or needs to be overpacked. Following movement from the retrieval face, a final inspection will be conducted to complete retrieval paper work and document conditions of the drum (Figure 6.1). The paper work should also record any special requirements of the retrieved containers such as shielding, venting, etc.

\subsubsection{Current SWBG ISB Approach}

Retrieval and subsequent inspection of earthen covered containers is not authorized under the current SWBG ISB.

\subsubsection{Pilot Retrieval SAR Approach}

The Pilot TRU Retrieval Program retrieval authorization extended to drums that met the retrieval criteria cited in section 6.1 .2 and limited the overall retrieval number to 138 drums. Literally all inspection to section 6.1.2 retrieval criteria was done at the retrieval face site or while on the single-drum skid prior to movement of the drum to the fourdrum skid used for shipping preparation.

It should also be pointed out that while the Pilot Retrieval Program only retrieved 23 drums from two separate trenches, approximately 250 drums were ultrasonically inspected. Of these, one drum was found to have a pinhole near the top but drum metal surrounding the pinhole measured approximately 0.060 inches, well above the retrieval criterion of 0.042 inches.

By design, the decision to retrieve drums was made at the trench retrieval face. The SAR approach was that a drum that wasn't vented and didn't meet DOT site shipping criteria was unsafe to move. The 18,200 TRU unvented drums that have been retrieved and shipped to date from LANL and SRS show this assumption to have been overly conservative. The retrieved drums at those two sites have not met any DOT shipping standard and are shipped unvented approximately 0.5 miles over dirt roads to venting facilities. As no accidents at either site have been associated with shipping unvented, retrieved TRU drums, this approach represents an acceptable risk.

The preparations for shipping were made at the four-drum skid. These included the completion of the radioactive waste shipping papers, final surveys for shipment, labeling the drums and attaching a SWITS traveler to each drum. The drums were not banded to a pallet but were loaded individually onto the covered transport van. 


\subsubsection{LANL Approach}

After drums were retrieved with the Skytrak, they were moved to the final inspection and laydown area. At LANL this area was about 20 yards from the retrieval face. The retrieval data form was completed for each drum. The following new data were requested on the form:

- Retrieval date

- Surface dose rate

- Drum condition:

- Good

- Suspect - including descriptions of corrosion, dents and/or rust

- Damaged

- Repackaging requirements

- Overpack size

- Drum manufacture or purchase date

- General comments

The bolt through the lid ring was also checked to the original torque value. If the bolt was below the original shipping torque value of $40 \mathrm{ft} / \mathrm{lbs}$ it was retorqued to that value. Under no circumstances was the bolt loosened or the lid ring removed.

The following items were retained as shown on the original storage records:

- Drum size

- Content description

- Weight

- Any shipper labeling numbers

- Possible $\mathrm{H}_{2}$ generation above the Lower Explosion Limit (LEL) (This was a code based on the generating facility known waste streams.)

Where no data were found for a specific drum, whether lost or never recorded, the drum shipment data and best facility knowledge data were used.

Only drums reading $<100 \mathrm{mR}$ were stored on the storage pads. Some drums reading $>100 \mathrm{mR}$ were retrieved but were shielded and moved to the RH-TRU shafts. Drums that contained $>20$ plutonium equivalent (PE) curies were tagged with a special tag so they would be vented first. No evidence of bulged drums was found. Of the first 4,667 drums retrieved at LANL, less than 130 (about $3 \%$ ) required overpacking. The original estimate and design basis was $50 \%$ of the retrieved drums would require overpacking. 


\subsubsection{SRS Approach}

SRS wastes like LANL were declared active RCRA wastes that were not disposed. The goal of retrieval was to determine that the drums were fit for retrieval, vent the drums and move the drums to RCRA inspectable covered storage.

The SRS concept of drum inspection was very similar to LANL. If the drum passed a visual inspection where no serious defects were identified that would impact containment, the drum was sound for retrieval. SRS also did not see a need to generate a large volume of new documentation on each retrieved drum. Existing records were mainly used for retrieved drums. The only additional data gathered or conducted at retrieval were:

- A complete radiological survey of the drum (needed more for shipping purposes)

- General drum condition and corrosion

- Bar-code labeling

Retrieved drums that: (1) had radionuclide content $>0.5$ curies, (2) dose rate $>200 \mathrm{mR}$ contact, (3) surface contamination or (4) severe corrosion problems were individually segregated on plastic pallets for case-by-case disposition.

\subsection{RETRIEVAL OF CONTAINERS WITH QUESTIONABLE INTEGRITY}

Containers of questionable integrity can be safely retrieved provided precautions are instituted. Questionable integrity should be defined as doubt that the drum can provide complete and secure containment for its contents. Current TRU drum retrieval at both LANL and SRS has shown that retrieval of questionable drums has become part of the TRU retrieval program.

Drums that lack containment integrity include those that contain holes, appear damaged, or are corroded to a point that a second containment barrier is required. Determination of sound container integrity does not require anything beyond visual examination. The inspection of the drum need only demonstrate that the drum has sufficient integrity to meet the principal feature of providing containment. Drums that are sound and without holes, noticeable deterioration, or large damaging dents will be deemed fit for retrieval. Drums that lack the DOT stamp may be subjected to NDE to determine their fitness for retrieval or they may be overpacked as stated in Section 6.4.

Drums of questionable integrity can be moved from the stacked modules and placed in an overpack preparation area adjacent to the retrieval face. Prior to any movement, the drum condition can be well known from the initial inspection, including the drum bottom. It is suggested that the drum be placed in a plastic bag as it is moved from the module. At the overpack preparation area a plastic wrap material can be wrapped around the drum to 
hold the plastic bag tightly in place and provide a secondary confinement. The drum can then be placed in an overpack.

\subsubsection{Current SWBG ISB Approach}

Retrieval of any containers from earthen covered storage is not authorized under the current SWBG ISB.

\subsubsection{Pilot Retrieval SAR Approach}

Drums of questionable integrity were not allowed to be retrieved during TRU Pilot Retrieval. The drums had to pass in situ NDE testing to determine that the minimum wall thickness of the drum was 0.042 inches or greater (compliant with a DOE-17H drum).

As part of the 1994 Pilot TRU Retrieval retrieved drum tops, sides and bottoms were ultrasonically measured. After 14 years in earthen storage the results of 1320 drum inspection locations showed the average drum wall side thickness was 0.054 inches (range 0.034 to 0.081 ) and the drum bottom average was 0.053 inches. (New drum metal was 0.060 inches prior to rolling for the drum shape.)

\subsubsection{LANL Approach}

Although LANL and SRS have had far less drums of questionable integrity to retrieve than retrieval project design numbers, both sites have dealt successfully with the handling and retrieval of drums of suspect integrity. Less than $3 \%$ of LANL's retrieved drums required overpacking. This is much less than the TRU retrieval design standard of $50 \%$.

As LANL initially inspects the stacked drums, the lead uses his experience to judge if the drum is fit for retrieval. If the lead has any doubts about the integrity of the drum, a safety representative is brought in and together they assess the drum condition.

The LANL drums that are breached or that questionable integrity are overpacked. The drums are removed from the stack and placed in plastic bags about $3 / 4$ of the way up the drum. No special patching is placed over the area of the breach. Shrink-wrap is then run around the drum circumference several times to securely hold the plastic bag in place. No contamination has been attributed to badly corroded or breached drums after retrieval of nearly 10,000 drums.

LANL also has designed a plate that can be placed over the bottom of the drum, if the drum bottom is badly corroded or breached, to provide support to the drum bottom and aid in retrieval to the inspection and overpack area. 


\subsubsection{SRS Approach}

From the 8,800 TRU drums stored in earthen cover from 1974 to 1985 at SRS, only one drum had a corrosion pin-hole and required overpacking. The retrieval of TRU drums of questionable integrity never became an issue at SRS.

The original TRU retrieval design criteria called for overpacking $50 \%$ of the retrieved drums. Previous studied conducted at SRS in the 1980s and early 1990s predicted corrosion rates of 0.002 to 0.006 inches per year for drums stored under earthen cover (Kriikku, 1991). This report and others provided the data predicting the $50 \%$ drum failure rate. SRS had even purchased 2,000 85-gallon overpacks in anticipation of using the overpacks for badly corroded drums. 


\subsection{NDA AND DISPOSITIONING OF DRUMS}

The retrieved suspect-TRU drums with recorded TRU content of less than one gram will be non-destructively assayed to determine the radioactive material content. This assay will be used to confirm the TRU status of the drum or reclassify the drum as LLW.

When the TRU retrievable storage began in 1970, TRU waste was considered to be "waste with known or detectable contamination of transuranium nuclides" (AEC, 1970). In $1973,10 \mathrm{nCi} / \mathrm{g}$ was set as the limit to define TRU waste, and, in 1982, this limit was revised upward to $100 \mathrm{nCi} / \mathrm{g}$. Because of the changes in the definition of TRU waste as well as the methods by which waste was determined to be TRU, some fraction of the waste initially disposed of as TRU is considered to be LLW under current definitions. The NDA is necessary to partition the retrieved waste into LLW and TRU segments, thus ensuring that further processing of waste is performed only on that fraction determined most likely to be TRU.

It is assumed for planning purposes that approximately $50 \%$ of the drums will assay as LLW. These LLW drums will be re-interred in the SWBG. The remaining TRU drums will be managed by the TRU retrieval project.

\subsection{STAGING OF DRUMS FOR NDA}

After a drum is visually inspected and its structural integrity confirmed, it will be staged for NDA. The staging area will be located somewhere between the retrieval work face area and the NDA unit. Its actual location will depend upon space availability and constraints due to retrieval activities; however, its location will be such that transport distances for NDA will be minimized.

The movement of individual waste containers will be done with a forklift or equivalent equipment in accordance with existing SWBG procedures. If a larger batch of similar waste containers require movement, a truck may be used. The movement of multiple drums will be accomplished using a truck, covered van or other vehicle.

It is projected that the drum retrieval rate will exceed the assay rate. The NDA staging area will be sized accordingly to ensure adequate space is available for a potential backlog of drums awaiting NDA, however, drum movement will be planned to maintain minimum drum backlog requirements at assay.

The staging area will be defined by ropes or equivalent (i.e., chains, temporary fencing) and will be properly marked in accordance with applicable regulations and requirements. The drums will be adequately protected from the weather. The assay staging area maybe segregated (i.e., 55-gallon drums, 85-gallon drums, 85-gallon drums with shielding, etc.) to expedite assay of certain drum types. These measures will help maintain the integrity of the drums while staged, even though the staging time is expected to be relatively short. 


\subsubsection{Current SWBG ISB Approach}

The staging and assay of drums is authorized under the current SWBG safety authorization basis.

\subsubsection{Pilot Retrieval SAR Approach}

After drum condition was confirmed to be acceptable, the drum was positioned on an inspection platform at the excavation trench where final visual and NDE inspections were completed. The quad unit held up to four drums before the drums were individually loaded on a covered van for shipment to TRUSAF. The shipment of drums to TRUSAF consisted of no more than 16 drums at a time. Drums were placed on the first floor in preparation for assay.

\subsubsection{LANL Approach}

Non-destructive assay was not included within the scope of LANL TRU retrieval activities. LANL maintains the retrieved drums and boxes with their original assay value.

\subsubsection{SRS Approach}

Non-destructive assay was not included within the scope of SRS TRU retrieval activities. SRS maintains the retrieved drums, boxes, and culverts with the original assay values. Assay is an ongoing operation at SRS and the drums will be opened, sorted, inspected in the Visual examination Facility, and re-assayed prior to shipment to WIPP.

\subsection{NDA AND PARTITIONING OF TRU/LLW DRUMS}

The NDA will be a contractor-provided service with the contractor providing all necessary equipment, utilities, and personnel required to monitor and perform the analysis. On-site personnel will provide drum handling activities, including placement and removal drums from the assay system. The drums to be assayed will be moved to the mobile assay unit drum in-feed area using forklift or equivalent equipment.

The drums will be weighed, assayed and then moved out of the unit. The assaying process will include the required Quality Assurance (QA)/Quality Control (QC) analyses as specified by the contractor's statement of work. Following assay, the drums will be segregated according to waste type (TRU or LLW). 


\subsubsection{Current SWBG ISB Approach}

The staging and assay of drums is authorized under the current SWBG safety authorization basis.

\subsubsection{Pilot Retrieval SAR Approach}

Non-destructive assay of drums during the Pilot Retrieval Project was performed at TRUSAF. The assay of drums was bounded by the TRUSAF safety authorization basis documentation.

\subsubsection{LANL Approach}

Non-destructive assay was not included within the scope of LANL TRU retrieval activities.

\subsubsection{SRS Approach}

Non-destructive assay was not included within the scope of SRS TRU retrieval activities. SRS maintains drums with their original assay value.

\subsection{RE-INTERMENT OF LLW DRUMS}

The drums segregated as LLW according to the NDA results will be re-interred permanently within the burial grounds. The LLW drums may be staged prior to reinterment. The re-interment of the LLW drums will be in a trench to be specified later during project development. The drums will be moved to the LLW trench using a forklift or an equivalent piece of equipment. The drums will be placed in the trench according to current SWBG standards.

\subsubsection{Current SWBG ISB Approach}

The current SWBG ISB allows for the movement of drums within the burial grounds.

\subsubsection{Pilot Retrieval SAR Approach}

The Pilot Retrieval Project did not address the re-interment of LLW drums. 


\subsubsection{LANL Approach}

The LANL TRU Retrieval Project did not address the re-interment of the LLW drums because the retrieved drums were not to be re-interred, but moved to covered, inspectable storage in a RCRA-permitted facility.

\subsubsection{SRS Approach}

The LANL TRU Retrieval Project did not address the re-interment of the LLW drums. Drums retrieved at SRS were moved to a RCRA-permitted TSD facility.

\subsection{PREPARATION AND STAGING OF TRU DRUMS FOR SHIPMENT}

Following NDA (and drum venting if required - see Chapter 8), those drums determined to be TRU will be staged for to transport to a TSD unit. The staging area will be adequately sized to accommodate at least a truckload of drums. The shipment staging area could possibly be a segregated area within the NDA staging area, depending upon space availability.

Similar to the NDA staging area, the staging area will be defined by ropes or equivalent (i.e., chains, temporary fencing) and will be properly marked in accordance with applicable regulations and requirements. The layout of the staged drums will include adequate spacing between drums to allow for labeling, inspection, traveler completion, and final preparations for shipment.

\subsubsection{Current SWBG ISB Approach}

The staging of drums for shipment from the SWBG is presently covered under the safety authorization basis.

\subsubsection{Pilot Retrieval SAR Approach}

The NDA of drums retrieved under the Pilot Retrieval project was done at the storage facility (TRUSAF). Following NDA and venting, the drums remained in storage at TRUSAF. 


\subsubsection{LANL Approach}

Drums were staged within the facility or at the retrieval site for shipment. Drums were not palletized or banded prior to loading onto flatbed trucks for shipment. All required paperwork and surveys were completed prior to shipment.

\subsubsection{SRS Approach}

The retrieved drums were staged for shipment following drum venting. 


\subsection{DRUM VENTING}

The current planning for the TRU retrieval project is to initially retrieve only vented drums. Installation of the Hanford vent clip on TRU waste drums generated at Hanford began in 1978. The Hanford vent clip is a one-inch wide strip of stainless steel that protruded approximately 1.5-inches below the drum lid ring. It is anticipated that TRU drum retrieval will come upon a small number of drums that are unvented or the visible portion of the vent clip may have been destroyed during storage.

As a result, current project planning includes the potential need for the venting of some retrieved TRU drums. Only those drums that have no visible venting device and have been determined to be TRU will be staged for venting. The non-vented LLW drums will be re-interred without venting the container.

\subsection{STAGING OF DRUMS FOR VENTING}

Non-vented TRU drums will be transferred to the venting staging area using drum moving equipment. The staging of drums for venting will be similar to the staging areas in previous steps of the retrieval project. The staging area will be defined by ropes or equivalent (i.e., chains, temporary fencing) and will be properly marked in accordance with applicable regulations and requirements. The drums may be placed on pallets or a similar support structure as they await venting or in preparation for shipment to a venting facility.

Staged drums will have passed inspections and have been deemed retrievable. They will also be designated as TRU via records or assay. The drums will be bar-coded as required to maintain identity. A traveler with retrieval data, SWITS data and any venting preparation data will be affixed to the drum. The layout of the staged drums will include adequate spacing between drums to allow for ease in movement and placement of drums. Drums will not be stacked in the staging area. Drums of like size will most likely be kept together and may be batched for venting in this manner.

\subsubsection{Current SWBG ISB Approach}

Drum venting is not within the current scope of the SWBG ISB.

\subsubsection{Pilot Retrieval SAR Approach}

Drum venting was not included within the scope of the Pilot Retrieval project. 


\subsubsection{LANL Approach}

Drum venting is conducted in Building 54-33, another $\mathrm{RUBB}^{\circledR}$ structure containing drum cleaning and venting facilities. Building $54-33$ is about a quarter mile from the retrieval dome 54-226 over TRU pad \#1 and about half mile from the open air retrieval Pads \#2 and \#4. Following retrieval inspections, the drums are placed on a flat-bed truck for transport to the cleaning/venting facility. Upon arrival at the RUBB ${ }^{\circledR}$ structure, the drums are removed from the truck and placed on multi-wheeled dollies for easy movement within the $\mathrm{RUBB}^{\circledR}$ structure. The drums are first placed in a chained off staging area awaiting drum cleaning. Only after cleaning and venting will the drums will be transported to storage where they will be banded four to a pallet (non-combustible metal) and stacked three-high in an inspectable, RCRA-compliant, array in one of four RUBB ${ }^{\circledR}$ storage domes.

A drum is moved from the staging area to the drum cleaning area to remove a corrosion inhibitor applied to the drum prior to placement in retrievable storage. The drum cleaner is a non-hazardous cleaner that effectively removes the corrosion inhibitor. After cleaning, the drum is transferred to the venting side of the structure.

The drum remains on the multi-wheeled dolly throughout venting. The venting section of the facility is partitioned from the cleaning side by a Mylar ${ }^{\circledR}$ curtain. The curtain fills no functional purpose and is tied back much of the time. Venting is conducted one drum at a time to install the WIPP compliant $\mathrm{NucFil}^{\otimes}$ filter.

\subsubsection{SRS Approach}

Similar to LANL, drum venting is conducted remotely from retrieval in a RUBB ${ }^{\circledR}$ enclosure located approximately $1 / 2$ mile from the TRU retrieval pads. The SRS drums were not coated with a corrosion inhibitor. Once final inspections are complete the drums are staged adjacent to the retrieval trench. Labeling and bar-coding is completed for each drum and paperwork for moving the drums to the venting/storage facility is completed. A flat-bed truck was backed into the RUBB ${ }^{\circledR}$ structure (at the first two covered pads) or parked adjacent to the staging area (at the last three uncovered retrieval pads). Drums are loaded onto the flatbed truck with the forklift drum grabber. Drums are not palletized or banded. As at LANL, side rails are reset in the truck bed and the drums are moved to the venting facility.

The venting facility is one of several that were originally constructed for the storage of RCRA compliant newly generated wastes. The building is a sprung-structure with concrete floors and a spill barrier. Once inside the facility the drums are unloaded and staged for venting. All movements to and from venting are conducting using a fork-lift truck. Only after venting will drums be palletized and stacked in the facility. 


\subsection{DRUM VENT INSTALLATION}

Following staging, the unvented drums will be vented using the Container Venting System (CVS) or similar device. The self-contained CVS is mobile (can be moved on a truck) from site to site and is remotely operated from a console for worker safety.

The CVS attaches and seals to the top and drills through the drum lid, draws a drum gas sample through a vacuum chamber into gas sample bottles and is capable of lifting a drum weighing up to 3,000 pounds to and from the venting area. The drilling of the hole in the container lid is done with a spark resistant titanium nitride drill bit. The drum can also be backfilled with an inert gas following venting. $\mathrm{A} \mathrm{NucFil}{ }^{\circledR}$ filter or equivalent will then be manually installed. While attached to the drum, the CVS is sealed to the drum such that any emissions are released through the HEPA-filtered exhaust.

The system consists of three components:

- The drum piercing assembly, which weighs approximately 440 pounds and is lifted atop a drum for venting.

- The control console, which operates the drum piercing, evacuation, gas sampling, backcharging of the drum with inert gas, and the attachment and detachment of the drum.

- The drum piercing enclosure (optional), in which the drum is placed to be pierced.

The system operation is sequentially controlled through fail-safe, go-no-go console switching. Flashing switch lights on the console direct the operator to the next step of the operation. The operator initiates the next process step by pushing the flashing switch. After completion of the process step, the light on the switch remains lit and the next lighted switch in the sequence flashes. Operation of the CVS console logic can not go out of sequence. A small programmable onboard computer controls the operation sequence.

Current plans call for venting activities to occur in the SWBG, as close to the retrieval site as is practical. However, if the SWBG safety authorization basis modifications become prohibitively lengthy, or if air permitting becomes too restrictive, consideration will be given to moving the venting activity to the treatment complex.

Both SRS and LANL have successfully loaded and shipped unvented drums from the retrieval site and moved them to another location to be vented. SRS ships unvented drums approximately $1 / 2$ mile from the retrieval site to the venting location, and LANL ships unvented drums about the same distance. Both sites have shipped thousands of unvented drums without incident. 


\subsubsection{Current SWBG ISB Approach}

The SWBG safety basis does not currently address container venting operations. A USQ evaluation will need to be performed prior to initiating this activity. The USQ will determine if the safety basis will need to be modified and the extent of such modifications.

\subsubsection{Pilot Retrieval SAR Approach}

Drum venting was not included within the scope of the Pilot Retrieval project.

\subsubsection{LANL Approach}

All drums handled during the LANL retrieval effort were unvented and required installation of a NucFil ${ }^{\circledR}$ filter. The Drum Venting System (DVS) used was developed at LANL to provide for the venting of retrieved drums. The DVS design incorporated several Hanford drum venting concepts: drum drilling, drum seal, vacuum chamber design and multiple-cycle nitrogen drum back-fill capability.

The DVS can complete a drum venting cycle in 10-12 minutes. This value exceeds the original design criteria that required venting of a single drum to be completed in 20-30 minutes. LANL has vented 80 drums in a 12 -hour shift. The DVS only tests vented drum gases for hydrogen.

The DVS drum venting cycle starts by loading the cleaned drum onto the rollers that feed the drum onto the venting vessel base. The DVS venting vessel, attached to the glovebox base, is then lowered over the drum and seals in the lock position. The glovebox provides the containment and confined clean-up capability in the event the top of the drum lid becomes contaminated. The inflatable bladder raises the drum into the final seal and vent position at the base of the glovebox. The drill motor then engages to drill and set the drill-lancet assembly into the drum lid. The drill lancet, a joint SRS-LANL design, is topped with a NucFil ${ }^{\circledR}$ filter and is sufficiently long to penetrate the drum lid and inner 90-mil poly liner. As the drill passes downward through the drum lid and again as it passes into the 90-mil liner, gas samples are taken. The gas sample is monitored for hydrogen only. (The original DVS design did not include any head gas sampling. Hanford strongly suggested that the hydrogen monitor be added.) If hydrogen is detected above the lower explosive limit (LEL), the drum is purged with nitrogen. This purge cycle may be repeated as many times a necessary to lower the hydrogen level to below the LEL (four percent).

With the drill motor in the "insert" position, the HEPA-filtered glovebox is isolated from the drum chamber. As the drill motor is retracted to its restart position in the glovebox, the top of the drum lid can be surveyed for contamination. The glovebox is also used for loading the next drill-lancet assembly into the drill motor. 
The LANL drums, like SRS drums, have 90-mil plastic liners in the drums. Therefore, the drilling lancet must drill through the drum lid and the top of the 90-mil liner, located about two inches below the drum lid. LANL uses a short hollow drill bit welded to the bottom of the $\mathrm{Nucfil}^{\circledast}$ filter. The filter has a sintered-metal filter plate embedded in the $\mathrm{Nucfil}^{\circledast}$ filter instead of the activated carbon.

Hydrogen above LEL has been encountered in LANL TRU retrieved drums. Hydrogen levels up to 27 percent were reported. The drums are run through the DVS nitrogen purge cycle until hydrogen levels are maintained below LEL.

\subsubsection{SRS Approach}

The SRS TRU retrieval project would use contractor developed and supplied equipment to vent all retrieved drums. A Nuclear Filter Technology, Inc. (NFT) venting unit was utilized for the venting of all retrieved drums at SRS. The NFT design was basically taken from the final LANL design as LANL was mandated to send their DVS drawings to NFT. Therefore, the NFT design utilizes may design concepts for venting developed jointly by LANL, Hanford and SRS. The set-up and operation of the unit was contracted to NFT.

SRS is able to vent/purge 16 to 20 drums in a 10-hour operational day. But within that 10 hours approximately 1.5 hours are utilized each morning to conduct surveys, start-up, testing runs and running the gas chromatograph (GC) gas curves. The NFT system analyzes vented gases for total volatile organic compounds (VOC), hydrogen, and oxygen.

Operations starts with the unvented drum being set on the drum roller dolly by a forklift operator. The door to the vent/purge chamber is opened and the platform is rolled into the chamber. The drum is positioned in the chamber and the door sealed. The drum is then elevated by an air bladder to the top of the vent/purge chamber. The drum is weighed during the lifting process. The drum must weigh $<1,200$ pounds. The drill assembly, holding the drill/filter device, is then lowered from its storage position in the small glovebox atop the vent/purge chamber and stops on the drum lid as the drill bit touches the drum lid. A neoprene donut at the bottom of the drill assembly contacts the drum lid and forms a seal around the drill assembly. The vacuum chamber is evacuated to $4 \mathrm{psia}$. The drill sequence is then initiated and drill/filter assembly is drilled through the drum lid and 90 mil drum line (all TRU drums at SRS have a 90 mil liner inside). The DVS drills an off-center hole in the drum lid so the drill bit will not hit the 90 mil liner thickened dimple area in the center of the liner. Also, if the filter will not tap into the drum lid, another hole can be drilled and another filter set. The drill assembly drills intermittently so heat generation will be limited during the drilling process. Metal filings from the drilling do not interfere with the seal or cause problems in the vacuum system because they are gently blown away with intermittent blasts of nitrogen. Total drilling time is about 1.5 minutes. Airflow passes through the vent/purge chamber and through 
three stages of HEPA filtration. One filter is on the vent/purge chamber and the other two filters are in the filter housing prior to the exhaust stack.

Following drilling, an evacuated drum headspace gas sample and a 90 mil liner gas sample is analyzed. If the gas sample is higher than allowable limits, the drum is purged with nitrogen and re-sampled. After successful gas sampling results are obtained, the drill/filter assembly is threaded into the drum lid with the nutrunner, at a force of 12.5 foot-pounds. The drum is lowered and the HPT opens the survey door on the vent/purge chamber and obtains a smear of the drum lid. After a successful, contamination-free smear is obtained, the drum is removed from the vent/purge chamber. A silicone caulking is placed around the filter-drum interface to assure a tight seal is maintained for many years.

SRS experience is similar to LANL on detecting hydrogen above LEL in the unvented TRU drums. SRS reported hydrogen levels of 12 to 26 percent in a few drums. But oxygen levels analyzed in the high-hydrogen drums showed low levels of oxygen. The high-hydrogen drums would go through the nitrogen purge cycle of the NFT venting/purging system several time to lower the hydrogen to below LEL. SRS reported that the NFT venting system removes 12 percent hydrogen with each nitrogen purge cycle.

Even after venting the high-hydrogen drums, hydrogen levels would climb back to above LEL in as little as 48 hours. SRS believed that the filters were not designed to handle the high hydrogen generation rates. SRS did not have assistance of the assay unit, since it had been previously shut down, to determine if the drums contained high levels of plutonium.

SRS concluded that the high-hydrogen drums must be moved into storage within 24 hours of venting. The drums were to stay untouched in storage for a minimum of four months for hydrogen to diffuse from the drums.

Checking hydrogen levels in the vented drums stored for four months showed no drum gas exceeding LEL for hydrogen.

\subsection{RESTAGING OF VENTED DRUMS}

Following venting the drums will be transported to the staging area with the other TRU drums awaiting shipment to a TSD unit (see subsection 6.4). If the drums are vented at the treatment complex, the staging of the vented drums will occur at the treatment complex. Shipment of the vented drums from the venting area direct to the TSD may also be done. The drums may be palletized and banded as necessary to the transportation SARP. The drums should not be stacked until placed in the final TSD storage facility. 


\subsubsection{Current SWBG ISB Approach}

Drum venting is not within the current scope of the SWBG ISB.

\subsubsection{Pilot Retrieval SAR Approach}

Drum venting was not included within the scope of the Pilot TRU Retrieval project.

\subsubsection{LANL Approach}

After venting, the TRU drums are transported to one of the four RCRA compliant RUBB $^{\circledR}$ storage units. The drums are loaded and unloaded with the forklift truck onto the flatbed truck. At the storage units, the drums are placed four to a pallet (noncombustible metal pallet) and banded. The pallets are than stacked three-high in rows that have the required RCRA inspection spacing.

Drums will remain in storage until the facilities and equipment are designed and available to inspect, treat and repackage the waste containers for compliance to WIPP or for LLW disposal.

\subsubsection{SRS Approach}

Within 24 hours after venting, the drums are placed four to a pallet (plastic composite pallet) and stacked three high in one of the RCRA compliant storage facilities. Highhydrogen generating drums are kept separate in one of the facilities.

Drums will remain stored in this manner until the Visual Examination Facility (VEF) is completed and tested next fiscal year. SRS will use a glovebox within the facility to open, sort and inspect waste streams that have been proven to meet the WIPP WAC. The process is designed for sorting and inspecting one drum at a time and the design throughput is one drum per day. 


\subsection{DOCUMENTATION}

Waste characterization data for the suspect-TRU wastes in the SWBG are both an important input to and output of Phase I retrieval.

- The initial review of historical records will allow similar drums to be batched for retrieval operations.

- Review of historical records allows early identification of drums that may pose potential hazards to workers or require special handling.

- Careful documentation of the data collected during both the records review and the retrieval process will provide the characterization data necessary for the subsequent storage and processing of TRU drums in accordance with the waste acceptance process.

- Data gathered during Phase I TRU retrieval will aid in the planning of subsequent TRU retrieval efforts.

The following sections present a brief discussion of the documentation available for the initial records review, especially the SWITS database, as well as the proposed methodology to update the existing documentation with new data gathered during the retrieval process. Documentation of the data gathered from both historical records and retrieval is key to ensuring that retrieved TRU drums meet the waste acceptance criteria for safe and compliant storage at a TSD facility as well as for processing at WRAP.

\subsection{HISTORICAL RECORDS}

This section discusses the primary historical records available for suspect-TRU wastes: the burial records and the SWITS database, process knowledge, and the waste management documentation in effect at the time the waste was accepted at the SWBG.

\subsubsection{Burial Records and the SWITS Database}

Throughout the past forty years a number of documents and databases have been used to archive waste content data and track waste containers. The use of standardized burial records began about 1968 , and, although the information included on them has changed over time, microfilmed copies of the original burial records are available for the suspectTRU drums to be retrieved in Phase I. Records from the early 1970's include information on radioactive contents, drum weight, and generator. Later burial records contain physical content descriptions and, since 1987, information on the non-radioactive chemical waste constituents has been required. 
HNF-5597

The SWITS database is used to track the radioactive solid waste that has been buried or stored in the 200 Area burial grounds and waste storage facilities. Information on SWITS has been derived from the burial records. Information that can be tracked by SWITS for an individual waste container includes generator, container type and size, storage or burial location, radioactive contents, hazardous/corrosive contents, and waste form information.

\subsubsection{Process Knowiedge}

Understanding the processes that generated the retrievably stored, suspect-TRU waste at Hanford provides additional waste characterization data. Waste characterization reports that include significant discussion of process knowledge are available for the largest generators of suspect-TRU waste: the Plutonium Finishing Plant (Duncan et al., 1993), PUREX (Pottmeyer et al., 1993a), 231-Z (Pottmeyer et al., 1993b), the 325 Laboratory (Pottmeyer et al., 1993c), General Electric's Vallecitos Nuclear Center (Vejvoda et al., 1993), Babcock and Wilcox (Duncan, 1994a), and Westinghouse Advanced Reactor and Nuclear Fuels Divisions (Duncan et al., 1994b). As a group, these generators produced approximately $86 \%$ of the suspect-TRU waste in retrievable storage at the SWBG.

\subsubsection{Historical Waste Management Documentation}

All suspect-TRU waste to be retrieved was previously accepted into the SWBG under the waste acceptance criteria in force at the time the waste was accepted. The Hanford Site's historical waste acceptance criteria as well as former waste management requirements and waste handling and packaging practices may provide information of use in the planning of retrieval operations and in meeting waste acceptance criteria for the CWC, WRAP, and/or WIPP. These data have been documented in the Solid Waste Management History of the Hanford Site (Duncan, 1995).

\subsection{DOCUMENTATION OF DATA COLLECTED DURING PHASE I RETRIEVAL}

Data generated as a result of the retrieval process will be key to meeting waste acceptance criteria for safe storage in the CWC as well as for processing of the TRU waste through the WIPP Certification Process. This section describes the data that will be routinely generated during Phase I and how those data will be documented.

\subsubsection{Confirmation Assay Results}

All suspect-TRU waste was accepted into the SWBG under the waste acceptance criteria in force at that time. Because of changes in the definition of TRU waste as well as the methods by which waste was determined to be TRU, some fraction of the waste initially disposed of as TRU is considered to be LLW under current definitions (i.e., the waste 
contains $<100 \mathrm{nCi} / \mathrm{g}$ ). The primary purpose of the NDA step is to confirm the correct designation of suspect-TRU drums as either LLW or TRU.

Drum assay results will be retained with the drum paperwork on a Container Retrieval Data Form. In addition, the SWITS database will be updated to reflect the assay results and the final drum classification as either LLW or TRU.

\subsubsection{Container Retrieval Data Forms}

Information from the comprehensive records review as well as new data collected during the retrieval process (see Section 6.1) will be used to complete Container Retrieval Data Forms. The CWC waste acceptance personnel will review the data sheet per their WAC and document an independent decision regarding its acceptability for storage. Project scope will end once confirmed TRU wastes are transported to CWC.

\subsubsection{Updates to the SWITS Database}

In addition to creation of Container Retrieval Data Forms, the SWITS database will be updated to reflect information gained during the retrieval process. Key information that will be recorded in SWITS will include, but not be limited to, the following:

- Changes in the storage or disposal location of a waste container. This includes waste in 55-gallon drums as well as other containers that may need to be moved to permit the retrieval of TRU drums. (Barcode scanning may be used to expedite this update.)

- New waste type designations based on the NDA results.

- NDA values, as necessary.

- Surface dose rate.

- Drum weight for drums that have gone through the NDA process.

- Additions of vent clips and/or filter packs to the drums.

- Placement of a drum into an overpack. 


\subsection{SPECIAL PROCESSING ISSUES}

This retrieval process has been designed to handle the majority of the buried 55-gallon drums of CH-TRU waste that are to be retrieved from the SWBG. However, the process description must be able to accommodate drums with special processing needs. This chapter addresses a number of conditions that will need to be evaluated on a case by case basis.

\subsection{CLASSIFIED WASTE}

In the past, the Hanford Site received classified waste for storage and disposal. At the present time, the classified waste within the 200 West burial grounds is underground and requires no special security measures.

The excavation process for the classified waste that is stored in a vertically stacked module arrangement is no different than for the other retrievably stored TRU waste described within this document. Likewise, retrieval from other storage configurations (e.g., drums that are horizontally placed or in the TV-7 module) will be described within this chapter.

Prior to the excavation of the classified waste, the appropriate safeguards and security specialist will be contacted to determine if the waste can be de-classified and handled along with the unclassified waste. The safeguards and security specialist will also provide guidance in developing project security measures and a safe post-retrieval storage configuration, as applicable.

WHC-EP-0912 describes additional security measures that may be required during the retrieval of classified wastes (Anderson, 1996). Such measures might include the following:

- Development of a security plan consistent with DOE Orders

- Intrusion detection security type locks on all access portals

- Installation or fabrication of a hardened room within a CWC building

- Increased security patrols

\subsection{CRITICALITY}

There are several criticality documents for the waste within the burial grounds. These analyses evaluate the waste in the as-stored configuration of the drums. The drum evaluations were for the designed storage life of 18 years. However, in 1995, there was an extension granted for the drum lifetime based on the corrosion rates determined during 
the 1994 Hanford Pilot Retrieval effort. Below is a listing of the Criticality Safety Evaluation Reports (CSERs) that are impacted by the TRU Retrieval effort.

Table 10-1. Criticality Safety Evaluation Reports (CSERs) Impacted by TRU Retrieval Activities

\begin{tabular}{|c|c|}
\hline CSER Number & Remarks \\
\hline $78-015$ & W4C/T01 \\
\hline $79-035(0)^{*}$ & EBR II \\
\hline $79-035(1)^{*}$ & « \\
\hline $79-035(2)^{*}$ & $" 6$ \\
\hline $79-035(3)^{*}$ & 6 \\
\hline $79-046$ & Do with 81-020 \\
\hline $80-010$ & W4C/T01 \\
\hline $80-017$ & W4C/T01 \\
\hline $81-020$ & W4C/T01\&04 \\
\hline $83-006$ & W4C/T07 \\
\hline 84-001 & W4C/T07 \\
\hline $86-010$ & W4C/T07 \\
\hline $\begin{array}{l}91-003(0)^{*} \\
91-003(1)^{*} \\
91-003(2)^{*} \\
91-003(3)^{*}\end{array}$ & $\begin{array}{c}\text { Criticality Safety Review for 1978-1990 Burial } \\
\text { Ground Placements }\end{array}$ \\
\hline $92-007^{*}$ & EBRII \\
\hline $96-020^{*}$ & EBRII \\
\hline ARH-3016 Part 2 & W3A/T08 \\
\hline RHO-CD-115 & W4B/T07 (if retrieved) \\
\hline NEW & $\begin{array}{c}\mathrm{W} 4 \mathrm{~B} / \mathrm{T} 07 \\
303 \mathrm{C}-77-\mathrm{XX} \text { and } \\
303 \mathrm{C} 77-\mathrm{XX}\end{array}$ \\
\hline NEW & $\begin{array}{c}\text { W4C/T20 } \\
\text { EXXON Drums } \\
3421 X X-X X\end{array}$ \\
\hline
\end{tabular}

*NOTE: These CSERs will be reviewed and integrated with one new CSER addendum.

Additionally, there are 39 high fissile content sequences within the burial grounds that require further analysis prior to excavation and removal. These 39 sequences were analyzed in an as-shipped array from the burial shipment records. This resulted in an addendum to CSER 91-003, which evaluated the as stored configuration. This reduced the number of sequences requiring retrieval to three areas within the $4 \mathrm{~B}$ Burial Ground, Trench 7. The other sequences were excused from the time limit due to low fissile content within the as placed array. CSER 91-003 also extended the design life 18 to 28 years for painted drums and from 20 to 30 years for galvanized drums. 
For retrieval of the drums, the following criticality issues must be addressed:

- Container integrity is sufficient to prevent criticality concerns.

Previous inspections at Hanford and other sites conclude that drum integrity should not be suspect to the point of the drum failing catastrophically. A small number of containers may contain pinholes, but the majority of container steel is in tact. Containers that are visually examined and found to be breached or have suspect container integrity will be overpacked at the retrieval site.

- The containers can be handled within existing burial ground or CWC criticality documentation.

At the time of this document preparation, a separate task is identifying what CSERs need to be modified to encompass the TRU retrieval process. Retrieval activities the must be considered include staging of waste prior to shipment, drum labeling with criticality information, and methodology for receipt and safe storage at CWC.

\subsection{HORIZONTALLY-STORED DRUMS}

The retrieval of horizontally stored drums is within the scope of Phase 2 retrieval. However, from a programmatic aspect the retrieval process and retrieval of this waste stream poses some difficulty. The horizontal storage configuration was used between 1970 and 1974 in both the 200 East and 200 West burial grounds at the Hanford site for retrievable storage of TRU Waste.

These waste storage configurations were the first storage sites of TRU waste as defined by the AEC's Immediate Action Directive 0511-21 (AEC, 1970). These containers of waste with known or detectable contamination of transuranic nuclides were to be segregated, packaged, and stored in readily retrievable, contamination-free packages for up to 20 years.

The design of these trenches is a earthen V-shaped trench. The drums were placed horizontally on the soil bottom of the trench. The drums were stacked 6 to 7 high in a close pack configuration to the width of the $\mathrm{V}$ trench. The drums were covered with approximately 2 to 4 feet of soil. As the trenches were filled from the west, subsequent loads were driven over the filled portion of the trench. In some of the trenches, the soil was compacted with heavy earth moving equipment. Additionally, soil contamination has occurred within the 4-B burial ground Trench 11 from caisson loading activities. This contamination has been covered with clean fill.

Prior to the retrieval activities, a records review of the containers will be performed to obtain as much information regarding the waste containers as possible. The quality of the 
data available is somewhat limited, so a greater number of the containers will have unknown contents or locations. (The location data for container placements within a module began in 1974.) Additionally, as containers are uncovered, the containers may also have unidentifiable markings. These drums were placed into storage prior to venting devices and hydrogen recombiners being installed in the containers.

The enabling assumptions for retrieval of this storage array are:

- The container integrity is such that the drums can be lifted intact and placed in an overpack or transported without contamination spread.

- Retrieval at other sites has occurred to provide a broader knowledge base for container corrosion rates and operational knowledge of retrieval activities.

The remediation of the burial grounds for trenches with known soil contamination is not part of the retrieval effort. If contaminated soil is encountered during retrieval, the Personnel Protective Equipment (PPE) will be adjusted as directed by the Radiological Work Permit. Small amounts of contaminated soil may be placed in drums or boxes, and the packages will be staged as appropriate while the paperwork required for newlygenerated waste is developed. As necessary, larger areas of contamination will be fixed and the area posted as a soil contamination area. Contaminated soils may also be bulk disposed, as practical.

The soil removal activities will be performed consistent with Chapter 5, Excavation Activities. Since this array is not modularized, the amount of area uncovered will suitable for retrieval of drums and expand as necessary. As the drums are stacked to the edges and up the slope of the trench, excavation access from the sides will be somewhat limited. Since these drums are placed on their sides, the lifting equipment to remove drums from the stack will be a nylon sling or drum grapplers designed to grasp the top and bottom lips. This equipment would be an attachment to a forklift, crane, or other suitable lifting equipment.

\section{4. "V" TRENCH DRUMS}

The retrieval of the drums stored in the V-Trench is within the scope of Phase 2 retrieval. However, from a programmatic aspect the retrieval of this waste stream poses difficulties. The $\mathrm{V}$ trench was the first engineered storage location for drummed TRU waste. This storage configuration was used between 1972 and 1973 and is at the East-end of Trench 7 in the 200 West Burial Ground 218-4B. The V-trench is 100 feet long and has a storage capacity of about 1400 drums, divided into four compartments.

This trench was constructed as a 90 -degree V-shaped concrete slab. The cross section is essentially square, but oriented with corners at the bottom and top. When filled with drums, it was enclosed with a galvanized steel roof and covered with 4 feet of earth and gravel. In this design, the drums were separated from the soil and moisture to reduce 
corrosion during storage. The structure was designed to contain possible leakage from the drums within the structure. Stacking aids were not part of the design, and the drums rest on top of each other in a $45^{\circ}$ pattern.

The V-trench configuration was discontinued after the first module was filled. The Vtrench was expensive to design and construct. Additionally, container integrity was questioned because of the weight being applied to the bottom drums.

Prior to the retrieval activities, a records review of the containers will be performed to obtain as much information regarding the waste containers as possible. The quality of the data available is somewhat limited, so a greater number of the containers will have unknown contents or locations. (Location data for container placements within a module was not recorded before 1974.) Additionally, as containers are uncovered, the containers may also have unidentifiable markings making. These drums were placed into storage

prior to venting devices and hydrogen recombiners being installed in the containers.

Soil contamination has occurred within the 4-B burial ground Trench 7 from caisson loading activities. This soil contamination has not been fixed or covered with clean fill. The enabling assumption for retrieving waste from the V-7 Trench is that the soil overburden will not need to be handled as waste. As these drums were not in direct contact with the soil, it is also assumed that the corrosion of these containers is negligible and can be handled as sound containers.

The excavation of the V-7 trench will be required from both the north and south to uncover the entire section. This will be done using a front-end loader or a SKY TRAK ${ }^{\circledR}$ type vehicle with the front-end loader attachment. Hand tools or vacuum systems may also be used for any soil removal operations. It is required to remove the overburden from the entire area to access the metal fabricated cover. Once all of the overburden is removed from the trench, a crane will be required to lift the cover from the storage module. The cover will need to be removed in one piece. If corrosion has set in, and the roof can not be removed in one lift, then the cover can be cut-up and removed in manageable pieces.

Container removal will require a variety of lifting equipment. It is possible that it will require a crane to lift the drums from the module as well as an articulating man-lift to position the operator in proximity of the drum to place the lifting device and for inspection and survey needs.

\subsection{WASTE CONTAINERS REQUIRING SPECIAL HANDLING}

This section addresses some of the issues that might challenge the SWBG authorization basis. The resolution of these issues will be handled on a case by case basis. The containers that challenge the authorization basis are scattered throughout the burial grounds. The majority of the challenges are within the records themselves. The most recent information available is within the SWITS database. However, when this database 
was created, it was a conversion from an older database (R-SWIMS) that contained numerous errors. The errors consisted of typographical errors, incorrect conversion factors, and inconsistent data entry. Also, the conversion from R-SWIMS to SWITS was never QA verified, and the conversion may have built in additional errors, including recategorization of waste containers.

\subsubsection{High-Fissile Content}

For the purposes of this section, containers with high fissile content are those containing over $200 \mathrm{FGE}$. The high fissile content drums will challenge the dose equivalent Curie limits within CWC and the burial ground for placement and staging within these facilities. Additionally, the fissile content will also provide the limits of other radionuclides within the trenches.

Boxes located in 4-C burial ground (limited to Trench 1, 4, 20, and 29):

- Plutonium - 910 Grams in Trench 1, Module 6, Tier 3 (no container size given)

- Total Beta/Gamma - 40,000 Curies in Trench 1, with no module or tier listed (no container size given)

\section{5-Gallon Drums located in 4-C burial Ground (limited to Trench 1, 4, 20, and 29)}

- Natural Uranium - 278,000 grams in Trench 1, Module 4, Tier 3

- Depleted Uranium - 118,400 grams in Trench 4, Module 6, Tier 2

- Enriched Uranium - 13,680 grams in Trench 4, Module 15, Tier 3

- Thorium 232 - 1608 Grams in Trench 4, Module 1, Tier 4

- Plutonium 238 - 515 Grams in Trench 1, Module 4, Tier 4 (8 drums in same module and tier)

Other Containers in the 4-C burial ground (limited to Trench 1, 4, 20, and 29)

- 110-gallon drum 670 Grams Plutonium, Trench 1, Module 6, Tier 3

Boxes located in 4-B burial ground (limited to Trenches 7 and 11)

- Enriched Uranium - 86,090 Grams in Trench 11 (no module or tier given)

- Plutonium - 494 Grams in Trench 7 (no module or tier given)

- Total Beta/Gamma - 320 Curries in Trench 7 (no module or tier given)

\section{5-Gallon Drums in 4-B burial ground (limited to Trenches 7 and 11)}

- Natural Uranium - 171,000 Grams in Trench 11 (no module or tier given horizontal placement)

- Depleted Uranium - 108,000 Grams in Trench 7, Module 16, Tier 1 
HNF-5597

- Thorium 232 - 15,000 Grams in Trench 11, (no module or tier given)

- Thorium 232 - 9250 Grams in Trench 7, Module 16, Tier 2

- Total Beta/Gamma - 280 Curries in Trench 7, Module 16, Tier 4

- Total Plutonium - 238 Grams in Trench 7, Module 16, Tier 2

\subsubsection{High Weight}

Within burial ground 4-C, trenches $1,4,20$, and 29 , the weights of containers to be handled range from 50 pounds to 30,000 pounds. Additionally, there are 5 boxes with a volume of 252 cubic feet.

The heaviest container weights are as follows:

- Concrete Box - 83,000 pounds (218W-4C, Trench 07)

- Metal Box -29,100 pounds (218W-4C, Trench 04)

- 55-Gallon Drum - 2,630 pounds (218W-4C, Trench 20)

- FRP Box - 23,000 pounds (218W-4C, Trench 07)

- Double Drums - 312 pounds (218W-4C, Trench 04)

The heaviest 55-gallon drum to be handled in 4-C trenches 1, 4, 20 or 29 is 2,630 pounds. This drum is from Westinghouse Advanced Reactor Division. Additionally, there are 92 drums weighing over 1000 pounds.

In 4-B Burial Ground, trenches 7 and 11, the heaviest container is 45,000-pound box. The heaviest 55 -gallon drum that is to be handled within 4-B burial ground is 800 pounds.

\subsection{VISIBLY OVER-PRESSURIZED CONTAINERS}

It is uncommon for drums to become visibly over-pressurized within the burial grounds. Historically, they have become over-pressurized from organic compounds as opposed to hydrogen build-up. Since about 1978, all TRU waste containers were required to have a venting device. The venting devices consisted of either a vent clip or a NucFil ${ }^{\circledast}$ drum lid filter. These devices have been tested and have not shown a high failure rate.

If over-pressurized containers are encountered, they will be handled identically to the methods described within Chapter 8, Drum Venting, or as determined necessary by operations through enactment of emergency response procedures and requirements.

\subsection{ODD-SHAPED CONTAINERS}

There are several odd shaped containers that will need to be uncovered and relocated for future processing. The containers that need to be handled in this manner include: 
HNF-5597

- 110 gallon drums

- L-10 drums

- Metal boxes (various sizes)

- Plywood boxes

- FRP boxes (various sizes)

- Concrete boxes

- EBR II casks
- HEPA filters

- Miscellaneous cardboard boxes

- Miscellaneous packages, equipment piping, tanks, etc.

- Miscellaneous cylindrical containers

There are also containers within the burial grounds that will have to be relocated that are over 20 feet long, and others that have a volume greater than 250 cubic feet.

Initial inspection, for other than 30,55 , or 85 -gallon drums (double drums, metal boxes, FRP boxes, concrete boxes, tanks or other wrapped equipment), will use the Container Retrieval Data Form (see Figure 6-1). The initial inspection for these containers will verify the containers are fit for removal and relocation. Special moving and handling equipment may be required to retrieve and relocate these containers. This form will provide the assessment that the containers are fit for relocation to selected locations within the burial grounds. 


\subsection{REFERENCES}

AEC, 1970, Immediate Action Directive 0511-21, U. S. Atomic Energy Commission, Washington, D. C.

Anderson, B. C., 1989, Characterization Plan for Stored Contact-Handled Transuranic Waste, WHC-EP-0223, Westinghouse Hanford Company, Richland, Washington.

Anderson, B. C., and D. R. Duncan, 1989, Sampling Plan for Retrievably Stored ContactHandled Transuranic Waste at the Hanford Site, WHC-EP-0226, Westinghouse Hanford Company, Richland, Washington.

Anderson, B. C., 1991, Contact-Handled Transuranic Waste Characterization Based on Existing Records, WHC-EP-0225, Revision 1, Westinghouse Hanford Company, Richland, Washington.

Anderson, J. D., 1996, The History of the 200 Area Burial Ground Facilities, WHC-EP0912, Revision 0, Westinghouse Hanford Company, Richland, Washington.

Bushore, R. P., 1998, Solid Waste Burial Grounds Interim Safety Basis, HNF-SD-WMISB-002, Revision 3A, Waste Management Federal Services of Hanford, Richland, Washington.

Demiter, J. A., 1997, Transuranic Drum Retrieval and Venting/Purging at the Savannah River Site - Trip Report, SESC-97-259, SGN Eurisys Services Corporation, Richland, Washington.

Demiter, J. A., 1998, Transuranic Retrieval and Vent/Purging at the Los Alamos National Laboratory - Trip Report, Cogema-98-879, COGEMA Engineering Corporation, Richland, Washington.

Duncan, D. R., et al., 1993, Characterization of Past and Present Solid Waste Streams from the Plutonium Finishing Plant, WHC-EP-0621, Revision 0, Westinghouse Hanford Company, Richland, Washington.

Duncan, D. R., 1994a, Radioactive Waste Shipments to Hanford Retrievable Storage from Babcock and Wilcox, Leechburg, Pennsylvania, WHC-EP-0719, Revision 0, Westinghouse Hanford Company, Richland, Washington.

Duncan, D. R., 1994b, Radioactive Waste Shipments to Hanford Retrievable Storage from Westinghouse Advanced Reactors and Nuclear Fuels Divisions, Cheswick, Pennsylvania, Pennsylvania, WHC-EP-0718, Revision 0, Westinghouse Hanford Company, Richland, Washington. 
Field, J. G., 1992, Drum Explosion at the Fernald Site, Memo to Hanford Site Shippers dated August 19, 1992, Memo number 58100-92-JGF-130, Westinghouse Hanford Company, Richland, Washington.

Irwin, R. M., 1997, TRU Relocation Status Report, HNF-SD-WM-RPT-287, Revision 0, Rust Federal Services of Hanford, Inc, Richland, Washington.

Joyce, J. P., 1993, Radioisotopic Characterization of Retrievably Stored Transuranic Waste Containers at the Hanford Site, TI-517, Revision 0, Westinghouse Hanford Company, Richland, Washington.

Joyce, J. P., and M. R. Harker, 1993, Final Safety Analysis for Contact-Handled Transuranic Waste Drum In-Situ Inspection and Vented Drum Retrieval, WHC-SDWM-SAR-058, Revision 0, Westinghouse Hanford Company, Richland, Washington.

Kriikku, E. M., 1991, TRU Drum Corrosion Study (U), WSRC-TR-91-467, Westinghouse Savannah River Company, Aiken, South Carolina.

McCormick, 1998, Safety Analysis Report for Packaging (Onsite) Steel Drum, HNF2209, Revision 0, Waste Management Federal Services, Inc., Northwest Operations, Richland, Washington.

McDonald, K. M., 1999, Transuranic (TRU) Waste Phase I Retrieval Plan, HNF-4781, Revision 0, Waste Management Federal Services of Hanford, Richland, Washington.

Pottmeyer, J. A., et al., 1993a, Characterization of Past and Present Waste Streams from the Plutonium-Uranium Extraction (PUREX) Plant, WHC-EP-0646, Revision 0, Westinghouse Hanford Company, Richland, Washington.

Pottmeyer, J. A., et al., 1993b, Characterization of Past and Present Waste Streams from 231-Z, WHC-EP-0659, Revision 0, Westinghouse Hanford Company, Richland, Washington.

Pottmeyer, J. A., et al., 1993c, Characterization of Past and Present Waste Streams from the 325 Radiochemistry Building, WHC-EP-0696, Revision 0, Westinghouse Hanford Company, Richland, Washington.

Schmidt, J. W., et al., 1995, Westinghouse Hanford Company Operational Environmental Monitoring Report, Calendar Year 1994, WHC-EP-0573-3, Westinghouse Hanford Company, Richland, Washington.

Stevens, P. F., 1994, Safety Analysis Report for Packaging (Onsite) 85-Gallon Retrieval Drum, SD-TP-SARP-006, Rev. 0A, Westinghouse Hanford Company, Richland, Washington. 
Vejvoda, E., et al., 1993, Radioactive Waste Shipments to Hanford Retrievable Storage from the General Electric Vallecitos Nuclear Center, Pleasanton, California, WHCEP-0672, Revision 0, Westinghouse Hanford Company, Richland, Washington.

WHC, 1995a, Solid Waste Burial Grounds Interim Operational Safety Requirements, HNF-SD-WM-TSR-001, Revision 0, Westinghouse Hanford Company, Richland, Washington.

WHC, 1995b, Solid Waste Burial Grounds Interim Safety Analysis, HNF-SD-WMSARR-028, Revision 1, Westinghouse Hanford Company, Richland, Washington. 


\section{APPENDIX A}

\section{AN OVERVIEW OF THE SUSPECT-TRU WASTES RETRIEVABLY STORED AT THE SWBG}

The following table lists the burial grounds, and the specific trenches within those burial grounds, that contain solid waste containers labeled as TRU. Following a brief description of each burial ground, the number of suspect-TRU waste containers in each trench is given along with an estimate of how many of those containers will assay as TRU and LLW. Characteristics of each trench that may affect the TRU retrieval process are discussed briefly in the comments section.

\section{References:}

Duncan, D. R., 1995, Solid Waste Management History of the Hanford Site, WHC-EP0845, Revision 0, Westinghouse Hanford Company, Richland, Washington.

Johnson, D. M., 1994, Phase 2 Solid Waste Retrieval Trench Characterizations, WHCSD-W221-DP-01, Revision 0, Westinghouse Hanford Company, Richland, Washington.

WHC, 1994, Advanced Conceptual Design Report, Solid Waste Retrieval Facility, Phase 1, Waste W-113, WHC-SD-W113-ACDR-001, Revision 0, Westinghouse Hanford Company, Richland, Washington. 


\section{Table A-1. Overview of SWBG Trenches Containing Suspect TRU Drums (Data taken from Johnson, 1994; WHC, 1994; and Duncan, 1995)}

\begin{tabular}{|c|c|c|c|c|c|}
\hline Location & Comments & $\begin{array}{c}\text { Total } \\
\text { Suspect TRU } \\
\text { Containers }\end{array}$ & $\begin{array}{c}\text { Estimated } \\
\text { TRU } \\
\text { Containers }\end{array}$ & $\begin{array}{c}\text { Grams } \\
\text { TRU }\end{array}$ & $\begin{array}{c}\text { Estimated } \\
\text { LLW } \\
\text { Containers }\end{array}$ \\
\hline \multicolumn{6}{|c|}{$\begin{array}{l}\text { Burial Ground 218E-12B } \\
\text { Active } 1967 \text { to present. Received boxed waste from the PUREX Plant containing both plutonium and } \\
\text { mixed fission products. The only burial ground in the } 200 \text { East Area that contains TRU waste, } 218 E-12 B \\
\text { is a dry waste burial ground located } 150 \text { m north of the northwest corner of the } 241-C \text { tank farm. Drums } \\
\text { were stacked horizontally without tarp coverage before soil coverage. }\end{array}$} \\
\hline Trench 17 & $\begin{array}{l}\text { "V" trench; containers buried with } \\
\text { direct soil contact from May } 1970 \\
\text { through October } 1972 ; 88 \text { drums, } 1 \\
\text { metal box and } 2 \text { Hanford Standard } \\
\text { Cartons are designated as RH. }\end{array}$ & $\begin{array}{l}2660 \text { drums } \\
60 \text { boxes }\end{array}$ & $\begin{array}{l}320 \text { drums } \\
8 \text { boxes }\end{array}$ & $\begin{array}{l}130 \\
30\end{array}$ & $\begin{array}{l}2340 \text { drums } \\
52 \text { boxes }\end{array}$ \\
\hline Trench 27 & $\begin{array}{l}\text { Waste placed directly in soil; } 11 \\
\text { RH drums }\end{array}$ & 240 drums & 70 drums & 14 & 170 drums \\
\hline \multicolumn{6}{|c|}{$\begin{array}{l}\text { Burial Ground 218W-3A } \\
\text { Active } 1970 \text { to present. Located approximately } 1200 \mathrm{~m} \text { west of the 221-T Building, this burial ground } \\
\text { consists of } 50 \text { trenches running east-west. Some of the drums in this dry waste burial ground contain } \\
\text { classified material from Rocky Flats (and other sites) and were stacked horizontally with other waste } \\
\text { until 1975. After 1975, the classified material was segregated from other wastes and was stacked } \\
\text { vertically in earthen-bottom trenches. }\end{array}$} \\
\hline Trench S6 & $\begin{array}{l}\text { LLMW trench with } 6 \text { TRU waste } \\
\text { casks; } 5 \text { EBR II casks with } \\
\text { irradiated fuel pieces and } 1 \text { cask } \\
\text { labeled as TRU }\end{array}$ & $\begin{array}{l}5 \text { EBR II } \\
\text { casks } \\
1 \text { other cask }\end{array}$ & 5 casks & 9,800 & 1 cask \\
\hline Trench S9 & $\begin{array}{l}\text { LLW trench with } 235 \text {-drum } \\
\text { modules from Rocky Flats. } \\
\text { Modules are stacked } 2 \text { high on } \\
\text { end, with plywood under, between } \\
\text { and on top of drum layers. } \\
\text { Fiberglass reinforced nylon cover } \\
\text { draped on sides/cover before dirt } \\
\text { covered. }\end{array}$ & 70 drums & 6 drums & 27 & 64 drums \\
\hline Trench 04 & $\begin{array}{l}8 \text { drums with absorbed } \\
\text { contaminated oil. }\end{array}$ & 143 drums & 11 drums & 11 & 132 drums \\
\hline Trench 05 & $\begin{array}{l}\text { TRU drums primarily from Rocky } \\
\text { Flats }\end{array}$ & 360 drums & 205 drums & 1,200 & 155 drums \\
\hline Trench 06 & $\begin{array}{l}\text { One 30-gallon from } 222-\mathrm{S} \text { Lab has } \\
\text { a recorded dose rate of } 10,000 \\
\mathrm{mrem} / \mathrm{hr} \text { at } 50 \mathrm{~mm} \text {. Another } 213 \\
\text { drums had surface dose rates of } 10 \\
\text { mrem } / \mathrm{hr} \text { or higher. One HEPA } \\
\text { filter was recorded to be } 500 \\
\mathrm{mrem} / \mathrm{hr} \text { and } 4 \text { others } 10 \mathrm{mrem} / \mathrm{hr} \text {. }\end{array}$ & $\begin{array}{l}2182 \text { drums } \\
7 \text { boxes }\end{array}$ & $\begin{array}{l}1733 \text { drums } \\
1 \text { box }\end{array}$ & $\begin{array}{l}3,250 \\
186\end{array}$ & $\begin{array}{l}449 \text { drums } \\
6 \text { boxes }\end{array}$ \\
\hline
\end{tabular}




\section{Table A-1. Overview of SWBG Trenches Containing Suspect TRU Drums (Data taken from Johnson, 1994; WHC, 1994; and Duncan, 1995)}

\begin{tabular}{|c|c|c|c|c|c|}
\hline Location & Comments & $\begin{array}{l}\text { Total } \\
\text { Suspect TRU } \\
\text { Containers }\end{array}$ & $\begin{array}{l}\text { Estimated } \\
\text { TRU } \\
\text { Containers }\end{array}$ & $\begin{array}{l}\text { Grams } \\
\text { TRU }\end{array}$ & $\begin{array}{l}\text { Estimated } \\
\text { LLW } \\
\text { Containers }\end{array}$ \\
\hline Trench 08 & $\begin{array}{l}\text { High number of drums from } \\
\text { Rocky Flats. Concrete casks } \\
\text { contain irradiated fuel materials } \\
\text { from } 2 \text { experimental reactors }\end{array}$ & $\begin{array}{l}460 \text { drums } \\
53 \text { box/other } \\
22 \text { concrete } \\
\text { casks }\end{array}$ & $\begin{array}{l}225 \text { drums } \\
34 \text { boxes } \\
22 \text { casks }\end{array}$ & $\begin{array}{l}2,000 \\
430 \\
4,700\end{array}$ & $\begin{array}{l}235 \text { drums } \\
19 \text { boxes }\end{array}$ \\
\hline Trench 17 & $\begin{array}{l}\text { Boxed waste only. About half of } \\
\text { the boxes contain Division of } \\
\text { Military Application production } \\
\text { equipment. }\end{array}$ & 112 boxes & 77 boxes & 7,060 & 35 boxes \\
\hline Trench 23 & $\begin{array}{l}\mathrm{K} \text { Basin waste consisting of } \\
\text { storage basin filters and } \\
\text { miscellaneous waste. }\end{array}$ & $\begin{array}{l}6 \text { drums } \\
8 \text { boxes }\end{array}$ & $\begin{array}{l}6 \text { drums } \\
8 \text { boxes }\end{array}$ & $\begin{array}{l}0.6 \\
3\end{array}$ & \\
\hline Trench 30 & $\begin{array}{l}\text { Primarily K Basin storage basin } \\
\text { filters. Also lab waste from PNL } \\
\text { and reactor debris from } 105 \mathrm{~N} \text {. } \\
\text { Reactor debris and at least } 2 \text { drums } \\
\text { are RH. }\end{array}$ & $\begin{array}{l}29 \text { drums } \\
5 \text { boxes/other }\end{array}$ & 4 boxes & 2.4 & 1 other \\
\hline Trench 32 & $\begin{array}{l}4^{\prime} \times 4^{\prime} \mathrm{X} 4^{\prime} \text { boxes contain storage } \\
\text { basin filters with dose rate of } 450 \\
\mathrm{mrem} / \mathrm{hr} \text { when buried. }\end{array}$ & 2 boxes & 2 boxes & 1.3 & \\
\hline \multicolumn{6}{|c|}{$\begin{array}{l}\text { Burial Ground } 218 W-4 B \\
\text { Active } 1967 \text { - present. Located approximately } 150 \mathrm{~m} \text { northwest of the } 234-5 Z \text { Building, this burial } \\
\text { ground contains } 13 \text { trenches and } 10 \text { caissons. Three of the trenches contain TRU retrievable waste. }\end{array}$} \\
\hline Trench V7 & $\begin{array}{l}\text { This trench is a diamond-shaped } \\
\text { structure made up of a concrete } \\
\text { "V" bottom and metal cover. }\end{array}$ & 1320 drums & 405 drums & 3,000 & 915 drums \\
\hline Trench 07 & $\begin{array}{l}\text { Detailed characterization available } \\
\text { (Johnson, 1994). }\end{array}$ & $\begin{array}{l}8080 \text { drums } \\
67 \text { boxes }\end{array}$ & $\begin{array}{l}3174 \text { drums } \\
37 \text { boxes }\end{array}$ & $\begin{array}{l}47,320 \\
1,010\end{array}$ & $\begin{array}{l}4,906 \text { drums } \\
30 \text { boxes }\end{array}$ \\
\hline Trench 11 & $\begin{array}{l}\text { Drums and boxes placed } \\
\text { horizontally directly in soil }\end{array}$ & $\begin{array}{l}3140 \text { drums } \\
106 \text { boxes }\end{array}$ & $\begin{array}{l}1826 \text { drums } \\
77 \text { boxes }\end{array}$ & $\begin{array}{l}3,206 \\
1,460\end{array}$ & $\begin{array}{l}1314 \text { drums } \\
29 \text { boxes }\end{array}$ \\
\hline \multicolumn{6}{|c|}{$\begin{array}{l}\text { Burial Ground } 218 W-4 C \\
\text { Active } 1974-\text { present. This dry waste burial ground is located approximately } 150 \mathrm{~m} \text { west of the } 234-5 Z \\
\text { Building and consists of } 6 \text { retrievable waste trenches running east-west. The northernmost trench is the } \\
\text { Navy Core Barrel Trench. The other trenches contain plutonium-contaminated soil and drums of } \\
\text { assorted TRU wastes. The trenches are asphalt bottom trenches that were covered with plywood and } \\
\text { tarps when full and then topped with fill dirt. During early } 1980, \text { a heavy snowfall and rapid melting } \\
\text { caused flooding within some of the } 4 C \text { trenches. Drums were observed floating within trench T04 and } \\
\text { were recovered undamaged. }\end{array}$} \\
\hline Trench 01 & $\begin{array}{l}\text { Detailed characterization available } \\
\text { (Johnson, 1994). }\end{array}$ & $\begin{array}{l}5080 \text { drums } \\
124 \text { boxes } \\
46 \text { casks }\end{array}$ & $\begin{array}{l}4370 \text { drums } \\
101 \text { boxes } \\
46 \text { casks }\end{array}$ & $\begin{array}{l}142,000 \\
3,700 \\
32,700\end{array}$ & $\begin{array}{l}710 \text { drums } \\
13 \text { boxes }\end{array}$ \\
\hline
\end{tabular}


HNF-5597

Table A-1. Overview of SWBG Trenches Containing Suspect TRU Drums

(Data taken from Johnson, 1994; WHC, 1994; and Duncan, 1995)

\begin{tabular}{|l|l|l|l|l|l|}
\hline Location & \multicolumn{1}{|c|}{ Comments } & $\begin{array}{c}\text { Total } \\
\text { Suspect TRU } \\
\text { Containers }\end{array}$ & $\begin{array}{c}\text { Estimated } \\
\text { TRU } \\
\text { Containers }\end{array}$ & $\begin{array}{l}\text { Grams } \\
\text { TRU }\end{array}$ & $\begin{array}{l}\text { Estimated } \\
\text { LLW } \\
\text { Containers }\end{array}$ \\
\hline Trench 04 & $\begin{array}{l}\text { Detailed characterization } \\
\text { available for all modules } \\
\text { (Johnson, 19XX) }\end{array}$ & $\begin{array}{l}9856 \text { drums } \\
38 \text { boxes }\end{array}$ & Not estimated & $\begin{array}{l}\text { Not } \\
\text { estimated }\end{array}$ & Not estimated \\
\hline Trench 07 & $\begin{array}{l}\text { The concrete box is listed as } \\
\text { weighing about 83,000 lbs } \\
(\sim 38,000 \text { kg). 13 drums contain } \\
\text { TRIGA fuel. The majority of the } \\
\text { boxes are FRP boxes. }\end{array}$ & $\begin{array}{l}67 \text { drums } \\
73 \text { boxes } \\
13 \text { casks }\end{array}$ & $\begin{array}{l}18 \text { drums } \\
39 \text { boxes } \\
13 \text { casks }\end{array}$ & $\begin{array}{l}160 \\
8,460 \\
13\end{array}$ & $\begin{array}{l}49 \text { drums } \\
34 \text { boxes }\end{array}$ \\
\hline Trench 19 & $\begin{array}{l}\text { One 200-lb } 91 \text {-kg) drum of TRU } \\
\text { among 1,200 cubic meters of } \\
\text { LLW. }\end{array}$ & 1 drum & 1 drum & 0.15 & \\
\hline Trench 20 & $\begin{array}{l}\text { A few drums and no boxes with } \\
\text { dose rates over 10 mrem/hr and } \\
\text { only 2 drums over 100 } \\
\text { mrem/hr. }\end{array}$ & $\begin{array}{l}613 \text { drums } \\
29 \text { boxes }\end{array}$ & $\begin{array}{l}425 \text { drums } \\
26 \text { boxes }\end{array}$ & $\begin{array}{l}37,030 \\
2,424\end{array}$ & $\begin{array}{l}188 \text { drums } \\
3 \text { boxes }\end{array}$ \\
\hline Trench 29 & $\begin{array}{l}\text { Active 1984-89. Relatively } \\
\text { well characterized. }\end{array}$ & $\begin{array}{l}2544 \text { drums } \\
10 \text { boxes }\end{array}$ & $\begin{array}{l}2532 \text { drums } \\
10 \text { boxes }\end{array}$ & $\begin{array}{l}58,500 \\
1,250\end{array}$ & 12 drums \\
\hline
\end{tabular}




\section{CORRESPONDENCE DISTRIBUTION COVERSHEET}

Author

D. R. DeRosa
Addressee

Distribution
Correspondence No.

HNF-5597

Subject:

Process Description for the Retrieval of Earth-Covered Transuranic Waste Containers at the Hanford Site

\section{DISTRIBUTION}

\begin{tabular}{llllll}
\hline Name & Location & w/att & Name & Location & w/att \\
\hline Correspondence Control & A3-01 & X & K. L. Hladek & G1-32 & X \\
M. D. Aichele & T4-04 & X & K. M. McDonald & H6-06 & X \\
R. R. Ames & T4-56 & X & J. A. Pottmeyer & H6-06 & 2 \\
J. W. Biglin & L6-38 & X & D. R. Pyzel & T4-04 & X \\
T. L. Blackford & T4-05 & X & L. R. Richterich & T4-05 & X \\
R. P. Bushore & T4-56 & X & J. R. Rosser & T4-03 & X \\
R. R. Connolly & T4-05 & X & D. G. Saueressig & T4-04 & X \\
J. A. Demiter & H3-26 & 2 & T. E. Schrader & T2-05 & X \\
D. C. DeRosa & T4-56 & 2 & K. J. Svoboda & H6-06 & X \\
D. R. Duncan & R3-86 & X & G. C. Triner & T3-05 & X \\
E. M. Greager & G1-29 & X & D PC. & A 3 -94 & X \\
J. O. Hanley & T4-05 & X & C entral File & B $/-07$ & $X$
\end{tabular}

